\title{
Accounting Standards and Value Relevance of Accounting Information: A Comparative Analysis between Islamic, Conventional and Hybrid Banks
}

\author{
Serge AGBODJO \\ LGCO, University of Toulouse 3 Paul Sabatier, France \\ serge.agbodjo@iut-tlse3.fr \\ Kaouther TOUMI \\ LGCO, University of Toulouse 3 Paul Sabatier, France \\ kaouther.toumilajimi@univ-tlse3.fr \\ Khaled HUSSAINEY \\ University of Portsmouth (UK) \\ khaled.hussainey@port.ac.uk
}

\begin{abstract}
Purpose: The study investigates the value relevance of accounting information for Islamic, conventional and hybrid banks. It also investigates the moderation impact of IFRS adoption and AAOIFI mandatory adoption on value relevance of accounting information.

Design/methodology/approach: Using value relevance models, we run panel data regressions on 47 Islamic banks, 112 conventional banks and 42 hybrid banks (conventional banks with Islamic windows). Our study covers listed banks from 14 countries over the period 2010-2018.

Findings: Our paper offers three empirical evidences. First, we find that value relevance of accounting information is higher for Islamic banks, compared to conventional banks. Second, we find that IFRS framework strengthens the relevance of accounting information in Islamic banks, but we did not find the same for Hybrid banks. Third, we find that the mandatory adoption of AAOIFI accounting standards has a moderation effect on value relevance of accounting information for both Islamic banks and Hybrid banks. The robustness analysis shows that there is a significant contribution of compliance with Islamic Finance rules in IBs and HBs, which substantially reduces managers' opportunistic behavior to manage accounting information.
\end{abstract}


Practical implications: The study is useful for investors that consider the Islamic ethical practices to make their investment decisions as well as for the standards-setting bodies that focus on establishing accounting standards for the Islamic banking industry.

Originality/value: We contribute to value relevance literature by providing novel evidence on the value relevance in fully-fledged Islamic, fully-fledged conventional and Hybrid Banks. We also provide new evidence on the moderating role of IFRS and AAOIFI for the value relevance of accounting information.

\section{Classification code}

G21 Banks • Depository Institutions • Micro Finance Institutions • Mortgages

M41 Accounting

Z12 Religion

\section{Key words}

Value relevance; Islamic banking; IFRS; AAOIFI. 


\section{Accounting Standards and Value Relevance of Accounting Information: A Comparative Analysis between Islamic, Conventional and Hybrid Banks}

\section{Introduction}

The Islamic banking sector with its economic significance is an attractive industry for investors seeking for ethical investment opportunities. The success of Islamic banking has been boosted further when multinational and conventional banks began providing Islamic products and Islamic windows. Despite their specificities with regards to the strict moral constraints that shape the particular context of their business model, banks offering Islamic financial services and products remain financial intermediaries that carry out financial transactions and listing on financial markets. They have to attract investors and raise funds to guarantee their continuity and survival. Similar to all actors in the capital markets, IBs are required to disclose accounting and financial information that investors need for investment decision purposes. For the IASB (2008) conceptual framework, the fundamental qualitative characteristics of accounting information are the relevance and the faithful representation. The relevance assumes that "financial information is capable of making a difference in the decisions made by users. Information may be capable of making a difference in a decision even if some users choose not to take advantage of it or already are aware of it from other sources"(IASB, 2010, p17). "To be a perfectly faithful representation, a depiction would have three characteristics. It would be complete, neutral, and free from error. Of course, perfection is seldom, if ever, achievable. The Board's objective is to maximize those qualities to the extent possible" (Ibid, 2010, p.17).

Value relevance studies examine how stock market react to accounting information (Ball and Brown, 1968). They assume that accounting information is relevant if it provides additional information to investors (Feltham and Ohlson, 1995; Ohlson, 1995; Collins et al., 1997). Previous studies on value relevance of accounting information focused on non-financial firms (see Amir $e t$ al., 1993; Harris et al., 1994; Collins et al., 1997; Fields et al., 1998; Dhaliwal et al., 1999; Dumontier and Raffournier, 1999; Martinez, 2004; Lenormand and Touchais, 2009; Keener, 2011). Much attention is given in accounting literature to bank's value relevance (Dimitropoulos et al., 2010; Agostino et al., 2011; Anandarajan et al., 2011; Manganaris et al., 2016; Burke and Wieland, 
2017). Prior research focuses on conventional banks (hereafter, CBs) without addressing the differences with banks operating under Islamic finance principles.

Islamic banks (hereafter, IBs) are a unique context to study the contribution of religious and ethical dimension on accounting reliability, more particularly Islamic ethical dimension. IBs are considered as having ethical identity, since the foundation of their business philosophy is closely tied to religion (Haniffa and Hudaib, 2007; Nienhaus, 2011). IBs follow particular ethical principles making them distinctive, such as the profit and loss sharing, the ban on dealing with interest, the tangibility and traceability of money, the transparency requirement, the ban on speculation and high risk-taking, and the requirement for investing funds in socially responsible assets. Conformity with the Islamic finance ethics in the field of financial management leads to innovative forms of bank business models and various governance frameworks compared with conventional banks. A Shariah supervisory board (Hereafter, SSB) ensures the conformity of IBs' activities with the Islamic finance ethics. Shariah supervision by SSBs is highly required among the overall governance system in order to protect stakeholder's interests, outside investors included, toward Shariah compliance (Almutairi and Quttainah, 2017; Farag et al., 2017; Basiruddin and Ahmed, 2019).

IBs present relevant features that could enhance the relevance of accounting information encouraging outside investors to place confidence in IBs financial reports in order to make investment decisions. To the best of our knowledge, the study of Kadri (2016) is a first attempt to analyse value relevance of accounting information in IBs. Kadri (2016) examines the value relevance of book value and earnings of 11 Malaysian Islamic and 9 conventional banks from 1998 to 2012. Kadri (2016) shows that, although book value and earnings of IBs and CBs are relevant, those of IBs remain low compared to CBs. Our research extends and goes beyond Kadri's (2016) in two important ways. First, we explore the value relevance of accounting information for an international sample of banks offering conventional and Islamic financial services. Second, we investigate the moderating role of accounting standards on value relevance of accounting.

Indeed, the objective of our research is to empirically examine the relevance of the accounting information, notably the earnings and book value per share, disclosed by IBs in comparison with CBs. First, we examine the value relevance of accounting information disclosed 
by IBs, CBs and Hybrid banks ${ }^{1}$ (hereafter, HBs). Second, we investigate the moderation role of International Financial Reporting Standards (IFRS) and Accounting and Auditing Organization for Islamic Financial Institutions standards (AAOIFI) on the value relevance of accounting information.

Using a sample of 201 banks categorised into 47 IBs, 112 CBs and 42 HBs from 14 countries over the period 2010-2018, our analysis reveals three main results. Firstly, we provide evidence that the value relevance of accounting numbers is higher for IBs and HBs, compared to CBs. Secondly, we find that IFRS strengthens the relevance of accounting numbers in IBs but no moderation effect of IFRS on value relevance is detected for HBs. Thirdly, we find that the adoption of mandatory AAOIFI accounting standards has a moderation effect on value relevance of accounting numbers in IBs and HBs.

Our study offers several contributions. First, to the best of our knowledge, we provide new cross-country empirical evidence on the value relevance of accounting information for IBs, CBs and HBs. We also provide new evidence on the moderating role of accounting standards on the value relevance of accounting information in the banking industry.

The reminder of the paper is organised as follows. Section 1 reviews the literature and develops the hypotheses. Section 2 discusses the research design. Section 3 presents and discusses the empirical results. Section 4 highlights the robustness analysis and section 5 concludes.

\section{Literature review and development of hypotheses}

\subsection{Value relevance of accounting information}

Ball and Brown (1968) is a pioneer study on the value relevance of accounting information. Information is considered value relevant if stock price movements are associated with the release

\footnotetext{
${ }^{1}$ We follow the classification of (Mohamed et al., 2020) of banks. Hybrid banks are conventional banks with Islamic windows. An Islamic window is a separate department within a conventional bank operating under strict surveillance of SSB to develop and offer Islamic financial products and services to the clients that demand such products and services.
} 
of such information. Holthausen and Watts (2001) distinguish three types of research on Value relevance that associate accounting information with the market value of equities, including relative association studies. The latter measures the relation between share market value and different measures of earnings (see Amir et al., 1993; Harris et al., 1994; Collins et al., 1997; Fields et al., 1998; Dhaliwal et al., 1999; Dumontier and Raffournier, 1999; Martinez, 2004; Lenormand and Touchais, 2009; Keener, 2011). The relevance of accounting information is often assessed by the coefficient of determination $\mathrm{R}^{2}$ (Collins et al., 1997). The higher the values of $\mathrm{R}^{2}$, the greater the explanatory power of the accounting numbers. According to Dumontier and Raffournier (2002), globally, most studies on value relevance use the net income as accounting number with relatively low obtained values of $\mathrm{R}^{2}$ ( $\mathrm{R}$ squared). For example in Europe, they are $10 \%$ in the United Kingdom, $7 \%$ to $17 \%$ in Germany, $1 \%$ to $29 \%$ in Denmark, and $1 \%$ to $49 \%$ in France (Dumontier and Raffournier, 2002). To improve the explanatory power of the models, different ways were considered which involve the implementation of non-linear relations between market value and accounting numbers (Martinez, 2004; Ahmad, 2006), the consideration of longer study periods (see Collins et al., 1997) or the use of panel data regressions (Collins et al., 1997; Dumontier and Labelle, 1998). Prior studies examined value relevance in financial markets of developed countries (see Dumontier and Labelle (1998) for the French context and Collins et al. (1997) for US context). Studies have been also extended to study value relevance in emerging markets (see Alali and Foote (2012) for Abu Dhabi; Al-Hares et al. (2012) for Kuwait; Qu and Zang (2015) for China and Lee and Lee (2013) for Taiwan).

Empirical studies on bank's value relevance are less abundant. Most previous studies exclude financial firms due to the special nature of their financial services, and focus on nonfinancial firms. Differences in international accounting standards also make it difficult to evaluate bank financial statements across different countries (Anandarajan et al., 2011). Research on value relevance in banks focused on the value relevance of derivative disclosure information in banks under specific accounting standards (Barth et al., 1996; Eccher et al., 1996; Nelson, 1996; Venkatachalam, 1996). Nelson (1996) evaluates the association between the market value of banks' common equity and the fair value estimates disclosed under the Statement of Financial Accounting Standards SFAF No.107 of the largest US banks (146 banks in 1992 and 133 banks in 1993) for the period 1992-1993. The results suggest that only the reported fair values of investment securities 
have incremental explanatory power relative to book value. However, the study does not provide reliable evidence of incremental explanatory power for the fair value disclosures of loans, deposits and long-term debts. For the same period, Eccher et al. (1996) examine the value relevance of fair value data disclosed under SFAS No. 107 on 293 banks during 1992 and 319 banks during 1993. Their results suggest that differences between fair and book values of financial instruments are associated with market-to-book ratios. However, fair value disclosures for financial instruments other than securities are value relevant only in limited settings. In contrast with Eccher et al. (1996) and Nelson (1996), Barth et al. (1996) find incremental explanatory power for loan fair values on sampled banks close to that used in Nelson's research (1996). With the same idea, Venkatachalam (1996) investigates the value relevance of banks' derivatives disclosure provided under the SFAS No.119 and finds that fair value disclosure for derivatives helps explaining cross-sectional differences in bank stock prices.

Added to the latter studies on value relevance of financial instruments held by banks before and after the introduction of new financial accounting standards, studies have considered the relevance of bank accounting information as a whole (Abuzayed et al., 2009; Dimitropoulos et al., 2010; Agostino et al., 2011; Anandarajan et al., 2011; Manganaris et al., 2015, 2016; Burke and Wieland, 2017). i.e. Abuzayed et al. (2009) show a value relevance of the net income in Jordanian banks over the period 1993-2004. They also find that the components of net income are more important than the aggregate net income in explaining bank value in the Jordanian Stock Exchange. Dimitropoulos et al. (2010) examine the informational quality of annual accounting earnings within Greek banking institutions over the period 1995-2004 and find that earnings have higher incremental importance in explaining stock return movements compared to cash flows. Anandarajan et al. (2011) find that book value of equity and earnings have value relevance with respect to equity valuation on a sample of 813 banks from 38 countries for the period 1993-1994. The authors also find that value relevance in banks is significantly affected by the transparency and the level of financial information disclosure requirements in the countries considered as well as the legal environment. At the bank-specific level, the authors reveal that the organizational form and the risk level have the most important impact on bank value relevance.

With regards to IBs, we find, to the best of our knowledge, only Kadri (2016) investigates the value relevance of book value and earnings in one IB (compared with six CBs), listed in Bursa 
Malaysia for the period 1998-2012. Kadri (2016) shows that the book value and earnings of Malaysian banks are value relevant. The author also observes that the book value and earnings of IBs and $\mathrm{CBs}$ are value relevant when they are separated. The author also finds that the explanatory power towards market value provided by IBs (with $\mathrm{R}^{2}=6.3 \%$ ) is far behind CBs (with $\mathrm{R}^{2}=69.2$ $\%)$. We complement this study by providing a cross-country evidence on the value relevance on accounting information in the banking sector (IBs, CBs, and HBs).and the moderating role of accounting standards.

\subsection{Value relevance of accounting information in IBs}

IBs present relevant features that could enhance accounting reliability encouraging outside investors to place confidence in IB financial reports in order to make investment decisions. IBs provide an interesting setting to test the role of Islamic religious norms on accounting reliability.

One of the main objectives of Islamic accounting is to enhance accountability by providing a fair information flow between the accountant and the accountee (Lewis, 2006). The accountability of financial institutions to a broad group of stakeholders requires ethics of enhanced disclosure and transparency in their corporate reports. From an Islamic perspective, players are required to fulfill the religious obligation of trust (Amana) forcing them to behave with respect to justice (Adl), balance (Qist) and perfection (Ihsaan) principles (Beekun and Badawi, 2005). The key objectives of Islamic accountability is the fulfillment of obligations to God, society, the environment and the self as well as the achievement of success in this world and hereafter (Falah) (see Kamla, 2009; Abdul-Baki et al., 2013; Mukhlisin, 2016). With regards to IBs, the Islamic accountability theory therefore extends the moral accountability of IB players (managers, board of directors, and SSB members) beyond their legal liability.

In pursuance of Falah, transparency in financial contracts and agreements is strongly advocated in an Islamic finance context since all stakeholders are required to be morally responsible with respect to each other. AAOIFI's Governance Standards for Islamic Financial Institutions stipulates that the Shariah review in IBs emphasizes the role of the SSB in corporate reporting reviews, which include the review of "contracts, agreements, policies, products, 
transactions, memoranda and articles of association, financial statements, reports (especially internal audit and central bank inspection), circulars, etc. " (AAOIFI-GS2, 2015). By reviewing the financial reports, the SSB is expected to exert some influence on the disclosure aspects of the IBs (Abdullah et al., 2015). The external and internal Shariah reviews reduce inaccuracies in financial statements and intentional misstatements (fraud), and help to disclose pertinent and reliable financial information. The SSB works to ensure that the financial interests of all stakeholders are protected to avoid a situation of incomplete information. A lack of transparency in IBs in this regard could lead to information asymmetry with their stakeholders exposing the bank to Gharar $^{2}$ (Abdullah et al., 2015). Consequently, these features enable each stakeholder, including investors, to benefit theoretically from equal, adequate and accurate information.

Furthermore, the Shariah supervision ensured by the Shariah governance mechanisms, such Internal and external Shariah review and audit, allows better control of the traceability and the management of the funds. Dimitropoulos et al. (2013) show that banks characterised by increased audit quality present a higher value relevance of earnings and book value of equity compared to firms of a lower audit quality. Besides, the Islamic finance requirement of traceability of funds, the strong link with real economy and the restricted set of investment opportunities (non-speculative and non-high-risk investments as Shariah constraints on speculation and gambling) allow outside investors to have clear view of the quality of IB assets, the related risk profile and the use of funds (Toumi et al., 2012). Complying with Islamic finance rules leads to reduced information asymmetries with outside investors helping them to trust the bank activities and to rely on the disclosed financial information to make investment decisions.

In addition, organisational religiosity induces social norms that could suppress the opportunistic behavior of individuals (Weaver and Agle, 2002). Ethics and religious norms appear to enhance the quality of accounting numbers by reducing unethical business activities such as opportunistic earning management (Brief et al., 1996). Dyreng et al. (2012) highlight that firms with a higher level of religious adherence report a lower likelihood of financial restatement and have less risk of fraud. In this context, managers of religious oriented organizations are more likely

\footnotetext{
${ }^{2}$ The Gharar is one of the three fundamental prohibitions of Islamic Finance (together with Riba 'interest' and Maysir 'speculation'). Gharar means uncertainty, hazard, ambiguity and imprecision.
} 
to adopt certain moral norms associated with anti-manipulative behavior. Consequently, opportunistic behavior by IB managers is also likely to be reduced (Safieddine, 2009; Toumi et al., 2012; Abdelsalam et al., 2016; Farag et al., 2017;) since moral accountability is likely to reduce risk-taking behavior (more conservatism) and discourage or mitigate earnings management practices (Abdelsalam et al., 2016; Elnahass et al., 2018; Lassoued et al., 2018). Abdelsalam et al. (2016) show that IBs report less discretionary accruals and are more conservative in relation to CBs. Lassoued et al. (2018) find that IBs manage their earnings less than CBs. Their result confirms the importance of organizational religiosity on corporate decision-making since the religious orientation of IBs enhances financial reporting reliability. Elnahass et al. (2018) find significant differences in earnings management behavior between IBs and CBs and detect a less significant use of loan loss provision (LLP) to manage earnings in IBs relative to their conventional peers.

In sum, IBs see accountability as Amanah towards God, owners and all stakeholders according to the Islamic accountability theory. IBs seem less prone to earnings management, which would reduce financial reporting risk in these banks. Managers are also expected to prepare reliable financial statements and disclose pertinent and reliable financial information. The Islamic finance context thus reflects the importance of integrity and ethical values and a commitment to reliable financial reporting, which helps banks operating in this context to have relevant accounting numbers.

Thus, we test the first hypothesis $\left(\mathbf{H}_{1}\right)$ : The accounting information of IBs are more relevant than those of CBs.

Several studies focused on value relevance of accounting information under several accounting standards. Financial statements are prepared either under local or international standards such as the IFRS. An important set of prior studies focus on the contribution of IFRS in improving value relevance of accounting information (Lenormand and Touchais, 2009; Agostino et al., 2011; Leventis et al., 2011; Dimitropoulos et al., 2013; Kim, 2013; Papadamou and Tzivinikos, 2013; Manganaris et al., 2015, 2016). Lenormand and Touchais (2009) compare the accounting information prepared under IAS/IFRS with the French accounting standards and find an increase in the relevance of earnings per share and equity under the IAS/IFRS standards. Anandarajan et al. (2011) argue that the extent of mandated accounting disclosure and the differences in accounting measurement practices in banks are the most influencing factors affecting 
the extent of value relevance of earnings and book values. Agostino et al. (2011), with using a panel of 221 European listed banks over the period 2000-2006, find that adopting IFRS enhances the information content of both earnings and book value for more transparent European banks. Leventis et al. (2011) find that the implementation of IFRS in the European commercial banks appears to have improved earnings quality by mitigating the tendency of managers of listed commercial banks to engage in earning management. Kim (2013) shows that the relevance of accounting information in the Russian financial market improves with the listing of Russian companies on the British market, where companies are subject to the IFRS standards, unlike the Russian domestic market. Manganaris et al. (2015) find an increase in the informativeness of earnings and a significant decrease in book value relevance after mandating IFRS within the European banking sector. The results of Manganaris et al. (2016) show that IFRS have reinforced the value relevance for both conservative and non-conservative EU banks.

Thus, we test the second hypothesis $\left(\mathbf{H}_{2}\right)$ : The IFRS accounting standards improves the value relevance of accounting information in IBs.

With regards to the Islamic Financial Institutions, special accounting and auditing standards have been developed through the accounting and auditing organization for Islamic financial institutions (AAOIFI), based in Bahrain and established in 1997. This body is contributing to the development of an accounting system that aims to link accounting standards and objectives to religious morality (Maurer, 2002; Kamla, 2009; Kamla and Rammal, 2013; Kamla and Haque, 2017;). The Islamic financial system has some unusual transactions that are not considered within the frame of the international financial reporting standards IFRS. The objectives of the AAOIFI accounting standards are the same as any other standards issued by international accounting bodies in the capital market: 'the provision of decision-usefulness facts for large investors' (Maurer, 2002). Concerns about "standardization", "decision-usefulness", and "possible regulatory interference" led to the establishment of the AAOIFI standards (Maurer, 2002). The aim of AAOIFI standards is first to increase market confidence in the activities of Islamic financial institutions; second, to render them comparable and finally to facilitate transfer of Islamic banking and finance practices across national and regulatory contexts (Maurer, 2002). Despite that for most Islamic financial institutions the AAOIFI standards are not mandatory; the AAOIFI has been successful in 
promoting its standards to Islamic financial institutions globally ${ }^{3}$. AAOIFI was not enacted to replace the IFRS; rather, it provides a complement that fills gaps between conventional and Islamic finance transactions (Hassan et al., 2019). For instance, the treatment of the mandatory charitable "zakat" distribution, the protection of unrestricted investment account holders' principal, and reserve funds for profit smoothing are some of the issues absent from the IFRS framework but are accounted for by the AAOIFI standards (Grais and Pellegrini, 2006). So establishing specific standards that focus on the Islamic specificities of Islamic contracts is necessary for fair treatment and accountability in the industry. Prior to AAOIFI, the Islamic financial institutions relied on the opinions of their SSBs, managers and auditors to solve problems related to accounting treatment in accordance with Islamic finance laws. Integrating and strengthening AAOIFI standards is essential to provide accountability, fairness and disclosure in Islamic financial transactions (Hassan et al., 2019).

Thus, we test the third hypothesis $\left(\mathbf{H}_{3}\right)$ : The AAOIFI accounting standards increase the value relevance of accounting information in IBs.

\section{Research design}

\subsection{Sample}

The sample consists of 201 listed banks from 14 countries categorised into 47 IBs, 112 CBs and 42 HBs (Table 1). Our study covers the period 2010-20184. Data are collected from the financial database Eikon-Thomson Reuters. All bank variables are winsorized at the $1 \%$ and $99 \%$ percentiles to reduce the influence of outliers and potential data errors.

\section{(Insert Table 1 here)}

\subsection{Econometric modeling}

The literature offers several models to examine the value relevance of accounting information (see Kothari and Zimmerman, 1995; Ohlson, 1995; Collins et al., 1997; Barth et al., 2008). Using the basic and most used model in the literature on value relevance (Kothari and Zimmerman, 1995;

\footnotetext{
${ }^{3}$ By 2020, AAOIFI accounting standards are adopted either fully or partially as mandatory regulatory requirements in 11 jurisdictions (Source : AAOIFI Website)

${ }^{4}$ Periods with the most complete data
} 
Ohlson, 1995) that associates market value of equity with book value and earnings, we run the following models:

$$
\begin{aligned}
& P_{i t}=\alpha_{0}+\alpha_{1} E_{P S} S_{i t}+\sum_{j=2}^{n-1} \alpha_{j} X_{i, t}+\alpha_{n} \text { DummyYear }+\varepsilon_{t} \\
& P_{i t}=\beta_{0}+\beta_{1} \text { BVPS }_{i t}+\sum_{j=2}^{n-1} \beta_{j} X_{i, t}+\beta_{n} \text { DummyYear }+\varepsilon t
\end{aligned}
$$

Where, $P_{t}$ is the price of a share of firm i three months after fiscal year-end $\mathrm{t}, E P S_{i t}$ is the earnings per share of firm $\mathrm{i}$ at the end of year $\mathrm{t} ; B V P S_{i t}$ is the book value per share of firm i at the end of year $\mathrm{t}$; $\mathrm{X}_{\mathrm{it}}$ is the Control variables; $\mathrm{n}$ : number of variables, $\alpha$ and $\beta$ are a regression coefficient; $\varepsilon$ is an error term.

As Dimitropoulos et al. (2010) argue, including both EPS and BVPS in the same model increases the efficiency of the estimation. We run the following model.

$$
P_{i t}=\gamma_{0}+\gamma_{1} E P S_{i t}+\gamma_{2} B V P S_{i t}+\sum_{j=3}^{n-1} \gamma_{j} X_{i, t}+\gamma_{n} \text { DummyYear+ } \varepsilon_{t}
$$

Furthermore, to test the moderation effect of IFRS and AAOIFI (as moderator variables), two regressions should be conducted to see whether the moderation effect occurs (Baron and Kenny, 1986; Aiken and West, 1991; Helm and Mark, 2012).

- The first basic regression predicts $P_{i t}$ from the moderator variable and the independent variables $E P S_{i t}$ and $B V P S_{i t}$ (See Eq. 4). Both variables should be significant.

$$
P_{i t}=\delta_{0}+\delta_{1} E P S_{i t}+\delta_{2} B V P S_{i t}+\delta_{3} I F R S+\sum_{j=4}^{n-1} \delta_{j} X_{i, t}+\delta_{n} \text { DummyYear }+\varepsilon t
$$

For IBs and HBs, we run additional regressions with "adopting mandatory accounting standards of AAOIFI" as a moderator variable.

- In the second regression, the interaction model, we add the interaction terms to the basic model. The moderation effect is indicated by the interaction terms EPS*IFRS and BVPS*IFRS in explaining $P_{i t}$. Moderation occurs when the interaction term is significant and $\mathrm{R}^{2}$ of the interaction model is higher. For IBs and HBs, we run additional regressions with "adopting mandatory accounting standards of AAOIFI" as a moderator variable. 
We control for year and country fixed effects in all models. We first run each model for the whole period with the examining value relevance for each category of banks (all banks, CBs, IBs and HBs). Secondly, we test the moderation effect of adopting IFRS on bank value relevance. Thirdly, we test value relevance for banks that mandatory adopt AAOIFI accounting standards. In all models, standard errors are adjusted thus controlling for potential heteroscedasticity.

We consider several control variables in our models. We add a bank specific variable such as the bank size (SIZE ${ }_{i t}$ ), the firms' risk profile measured by the leverage (LEV it) and the firm's operational performance (measured by the return on assets $\mathrm{ROA}_{\mathrm{it}}$ ) (Tahat and Alhadab, 2017). We also consider the following macro-economic variables: the stock market capitalization to GDP ratio $\left(\mathrm{SMC}_{\mathrm{t}}\right)$, the supervisory Pillar 3 disclosure requirements for banks (PIL3t), the GDP growth rate $\left(\mathrm{GDP}_{\mathrm{t}}\right)$, and the inflation rate (INFLt). Anandarajan et al. (2011) argue that the macro-levels are the most influencing factors affecting the extent of value relevance of earnings and book values. All variables are defined in table 2.

(Insert Table 2 here)

\section{Empirical results}

\subsection{Descriptive statistics}

Table 3 provides descriptive statistics. Our results reveal that the bank earnings' (EPS) has an average of $\$ 0.105$ per share with a higher value for HBs in average (\$0.119 per share for HBs versus $\$ 0.107$ per share for $\mathrm{CBs}$ and $\$ 0.088$ per share for IBs). Our results also show that the Book value per share (BVPS) has an average value of $\$ 1.171$ with a higher value on average for HBs ( $\$ 1.348$ versus $\$ 1.259$ for CBs and $\$ 0.790$ for IBs). With regards to the adoption of IFRS, $50.8 \%$ of sampled banks are implementing these standards. We have an evenly spread sample on the application of IFRS. More than 67.1\% IBs have implemented IFRS against 51\% for HBs and 44\% for CBs. Moreover, $33.1 \%$ of IBs and $26.9 \%$ of $\mathrm{HBs}$ implement the mandatory accounting standards of AAOIFI if relevant standards exist. Besides, $45.6 \%$ of banks disclose financial information related to risks in conformity with the Basel Pillar 3 - Market Discipline. The higher 
value is recorded for IBs where 56.9\% of these banks respect the Basel pillar 3 disclosure requirements (versus $52.3 \%$ for $\mathrm{HBs}$ and $38.3 \%$ for $\mathrm{HBs}$ ).

The Two-sample t-test (Two-tailed) highlights a mean difference for the majority of variables used, in particular for the stock price between CBs and banks offering Islamic financial services (IBs and HBs).

(Insert Table 3 here)

The matrix of Pearson correlation coefficients indicates relatively weak association between the explanatory variables (see Table 4).

(Insert Table 4)

\subsection{Regression results on value relevance in Islamic banks}

For the first step, we test whether earnings per share and book value of equity per share value relevance varies between the different categories of banks. The table 5 shows the empirical findings of regressions examining the value relevance of accounting numbers for the full sample (Culumns1-3), for CBs (Columns, 4-6), for IBs (Columns, 7-9) and for HBs (Columns 10-12). First, we investigate the relevance for EPS (Columns 1, 4, 7 and 10) as well as for BVPS (Columns 2, 5, 8 and 11). Second, we add both EPS and BVPS on the same regressions (Columns 3, 6, 9 and 12) to increase the efficiency of the estimation as Dimitropoulos et al. (2010) argue. All models are significant at $1 \%$ significance level.

(Insert Table 5 here)

When considering the results of regressions with separate EPS and BVPS in table 5, both accounting numbers are observed to be relevant at $1 \%$ level for all sampled banks (Columns 1-2) as well as for CBs (Columns 4-5), for IBs (Columns 7-8) and for HBs (Columns 10-11). Our results are in line with the previous literature on the relevance of the accounting informaiton in banks (Dimitropoulos et al., 2010; Agostino et al., 2011; Anandarajan et al., 2011). Besides, the results 
of regressions with both variables EPS and BVPS reveal a significance of the two accounting information at $1 \%$ level when we consider all sampled banks and the CBs (Columns 3 and 6).

Re-estimating the models for IBs, both the EPS and BVPS coefficients are positive and significant at $1 \%$ and $10 \%$ significance level respectively (Column 9). For HBs, BVPS is value relevant at $1 \%$ level but not the EPS (Column 12). More interestingly, the higher magnitude of EPS on stock price is observed for HBs when considering regressions with EPS only, followed by the IBs and the CBs (Columns 4, 7 and 10). We find that an increase of $1 \$$ in EPS increases significantly the stock price of HBs with $\$ 14.80$ (versus $\$ 5.60$ for IBs and $\$ 3.84$ for CBs). The same results are observed for BVPS when considering regressions with BVPS only (Columns, 5, 8 and 11). The results indicate that for every additional dollar in BVPS, we expect the stock price to increase significantly by $\$ 1.00$ for $\mathrm{HBs}, \$ 0.75$ for IBs and $\$ 0.18$ for CBs. The regressions with both EPS and BVPS give the same conclusions; HBs followed by the IBs appear to have the higher coefficients of EPS (columns 6,9) and BVPS (Columns 6, 9 and 12). The Islamic dimension seems to play a role in increasing the reliability of the financial information in these institutions and bringing confidence to the general public and the financial markets on the credibility of Islamic financial institutions.

Our results support the first hypothesis (H1) that the value relevance of accounting numbers will be higher for banks with Islamic ethical dimension. Our results are in line with the recent literature arguing that IBs see accountability as Amanah towards God, owners and all stakeholders according to the Islamic accountability theory. IBs seem less prone to earnings management, which would reduce financial reporting risk in these banks. Previous literature reports that managers of Islamic banks are more likely to adopt a certain conservatism in behavior on accounting rules and moral accountability associated with anti-manipulative behavior (Abdelsalam et al., 2016; Elnahass et al., 2018; Lassoued et al., 2018; Abdelsalam et al., 2020). Their empirical results put in evidence that banks following Islamic finance guidelines manage their earnings less compared with their conventional peers which leads them to divulge information of better quality to shareholders and induces a better value relevance. Besides, transparency and disclosure of more reliable financial information reduces the related agency costs between insiders and outside investors (Safieddine, 2009; Toumi et al., 2012; Abdelsalam et al., 2016; Farag et al., 2017). Furthermore, in pursuance 
of Falah, transparency in financial contracts and agreements is strongly advocated in an Islamic finance context since all stakeholders are required to be morally responsible with respect to each other. In addition, the Islamic finance rules, such as traceability, non-speculative and non-high-risk investments, leads to reduced information asymmetries with outside investors, helping them trust the bank activities. So, complying with Islamic finance ethics appears to give a signal to outside investors that they might benefit from equal, adequate and accurate information. The complementary checks carried out by SSBs, internal and external Shariah auditors is also an advantage for banks respecting Shariah rules, in addition to those traditionally performed by conventional auditors. Dimitropoulos et al. (2013) report that banks characterized by increased audit quality present a higher value relevance of earnings and book value of equity compared to firms of a lower audit quality.Size, as a proxy of bank market capitalisation, is highly significant at the $1 \%$ significance in all models in Table 4 (except for column 10) and carry a positive sign for all categories of banks. Larger banks tend to have higher stock price. Our result is consistent with the empirical literature on the significant association between the size and the quality of financial information provided by financial firms. Leventis and Dimitropoulos (2012) report that analysts tend to follow larger banks and these banks are less likely to engage in aggressive earnings management (Cornett et al., 2009). Abdelsalam et al. (2016) find that small-sized banks in the Middle East and North Africa (MENA) region engage in manipulative techniques in order to achieve earnings targets and that this situation could reduce financial quality and the relevance of accounting numbers. Furthermore, the size of banks is linked with a company's ability to bear the costs of disclosures of information that are likely to affect the stock price.

Transparency as measured by Pillar 3 disclosure is highly significant (at the $1 \%$ significance level) for all banks and sub-categories . Banks disclosing financial information related to risks as required by Basel Pillar 3 - Market Discipline framework tend to have lower stock price. For banks, Basel Pillar 3 framework complements the minimum capital requirements (Pillar 1) and the supervisory review process (Pillar 2). The Pillar 3 disclosures are an effective means of informing the market about the risks faced by a bank, and provide a consistent and understandable disclosure framework that enhances transparency and comparability. Our results suggest that transparency significantly influences market stock prices. Our finding is in line with that of (Anandarajan et al., 2011) arguing that greater levels of disclosure have a significant impact on the understanding and interpretation 
of financial statement numbers by investors. Greater disclosure implies greater understanding of the factors influencing the numbers underlying reported earnings, reducing thus stocks market value. The firms' level risk (LEV) negatively affects the CBs' market stock price (Columns 4-6). Unlike banks offering Islamic financial services, for which indebtedness is not a significant variable, investors react negatively to CBs' indebtedness.

\subsection{Regression results on value relevance in Islamic banks and IFRS}

According to our discussion, it is expected that the value relevance of earning per share and the book value of equity will be higher for banks adopters of IFRS. Table 6 presents the regression results for the moderation effect of adopting IFRS on the relevance of the accounting information for all banks, CBs, IBs and HBs.

(Insert Table 6)

Focusing on the basic models, we find that both EPS and BVPS are relevant at $1 \%$ level (Columns 1, 3, and 5) and second, that the implementation of IFRS impacts the market stock price with a significance at $1 \%$ level for all banks (Panel A) and at 5\% level for IBs (Panel C). For HBs, only the BVPS appears to be relevant and no significance is detected for the adoption of IFRS.

When considering the interactions models (Columns 2, 4, and 6), the moderation effect of adopting IFRS on the relevance of accounting numbers is confirmed for all categories of banks except for HBs (Column 8).

Going deeper in details, we detect a pure moderation effect of the implementation of IFRS for all banks (Panel A) as first the interaction terms EPS*IFRS and BVPS*IFRS are positive and significant at $1 \%$. The introduction of IFRS is thus observed to strengthen the relationship between EPS and BVPS with the stock price and contributes thus to greater value relevance of these accounting numbers. This finding verifies recent evidence provided by the literature on the increase in the relevance of accounting performance indicators for financial and non-financial firms under the IFRS (Lenormand and Touchais, 2009; Agostino et al., 2011; Leventis et al., 2011; 
Dimitropoulos et al., 2013; Kim, 2013; Papadamou and Tzivinikos, 2013; Manganaris et al., 2015, 2016).

In addition, the relevance of accounting numbers is confirmed under IFRS when we split the sample into IBs and CBs separately (Columns 3-6). For both categories of banks, our results demonstrate similar findings and indicate a pure moderation effect of adopting IFRS on EPS for $\mathrm{CBs}$ and quasi moderation for IBs value relevance while an absence of a moderation effect on BVPS value relevance (columns 4 and 6). Besides, the interaction terms EPS*IFRS are positive and statistically significant at $1 \%$ for CBs and IBs with a higher value of the coefficient for IBs (10.33 versus 8.5 for $\mathrm{CBs}$ ). The moderation effect of the application of IFRS on EPS is more important for IBs than for CBs, thus verifying H2. Adopting IFRS is observed to strengthen value relevance in IBs. We fail however to prove a moderation effect of adopting IFRS on accounting numbers relevance for HBs (Column 8)

To complement our analysis related to the first hypothesis H1, the coefficients of EPS and BVPS present a higher positive significant magnitude for IBs (4.78 for EPS and 0.92 for BVPS) relative to CBs (4.00 for EPS and 0.21 for BVPS) even when we add IFRS to regressions. For HBs, BVPS presents a higher coefficient (1.01) compared to CBs and IBs.

\subsection{Value relevance in Islamic banks and AAOIFI}

To investigate further the impact of AAOIFI introduction, we run additional regressions. According to our discussion, it is expected that value relevance will be impacted by the adoption of the mandatory accounting standards of AAOIFI (H3). Table 7 shows our findings.

\section{(Insert Table 7)}

Compared to the previous regressions in tables 4 and 5, we add AAOIFI variable to our models in table 6. Focusing on the basic models, we find first that both EPS and BVPS are relevant at 1\% level (Columns 1, 3, 5, 7 and 9) and second, the implementation of AAOIFI is positively associated with stock price for IBs (Panel C) and HBs (Panel D). This result shows that banks following 
Shariah rules and adopters of mandatory AAOIFI accounting standards tend to have higher stock price.

For the second step, we consider the interactions models. The moderation effect of adopting AAOIFI accounting standards on value relevance is confirmed for IBs and HBs. Focusing on IBs, we provide clear evidence that the EPS is less value relevant for banks adopting mandatory AAOIFI accounting standards, as reveal the significant and negative coefficient of the interaction term EPS*AAOIFI (Columns 2 and 6). However, BVPS is found to be more relevant under Mandatory AAOIFI framework as shown by the positive and significant coefficient of the interaction term BVPS*AAOIFI (Column 6). When considering HBs, we find opposite results. Contrary to IBs, mandatory adopting of AAOIFI accounting standards is observed first to strengthen EPS value relevance (Columns 8 and 12) and second, to weaken BVPS value relevance (Column 12) in HBs.

The moderation effect of adopting mandatory AAOIFI accounting standards on value relevance occurs but differently for IBs and HBs. Our findings reveal that outside investors are aware of the existence of AAOIFI accounting standards, where the standards are being used a reference in preparing financial statements. The divergence between results may be a signal that AAOIFI standards face difficulties to penetrate into the International Financial Institutions (hereafter, IFI) market which the industry is dominated by the western industry. AAOIFI was established with the aim of providing standards for Islamic finance that are harmonized with global practices. However, it faces various challenges that will require consolidated efforts to overcome them (Hassan et al., 2019). The adoption of AAOIFI accounting standards is voluntary in most countries and the standard-setting body lacks the power to enforce IFIs compliance with its standards (Kamla, 2009). Besides, AAOIFI explicitly reveals that its objectives and principles are based on conventional ones, adopting those that are consistent with Shariah principles, and excluding those that are not (Kamla and Hoque, 2017). The Islamic accounting literature gives examples linked to the failure of AAOIFI to offer an indigenous alternative to the Anglo-American logic. Indeed, AAOIFI's objectives and standards did not differ substantially from IASB's and like IASB, AAOIFI embraced concepts like private-self regulation and capital market-orientated standards and focused 
on the information needs of large multinationals represented by most powerful IFIs (Kamla, 2009; Maurer, 2002).

\section{The robustness analysis: alternative method of value relevance}

\subsection{Robustness models}

Beyond the price model presented in section 2, Barth et al. (2008) propose three value relevance metrics. The first metric is based on the explanatory power from regressions of stock price on earning per share and equity book value (See Eq 5). The second and third metrics are based on the explanatory power from regressions of earning per share on annual stock return (See Eq6).

The first metric of value relevance is the adjusted $\mathrm{R}^{2}$ value from the regression given by:

$\mathrm{PRICE}_{\mathrm{it}}{ }^{*}=\mu_{0}+\mu_{1} E P S_{i t}+\mu_{2} B V P S_{i t}+\sum_{j=3}^{n} \mu_{j} X_{i, t}+\varepsilon t \quad(\mathrm{Eq} 5)$

To obtain a measure of price that is unaffected by mean difference across countries, we first regress

stock price $(\mathrm{P})$ on country fixed effect. Then, in a second step, the residuals from this regression (PRICE*) are regressed on EPS and BVPS separately for each category of banks with considering the adoption of IFRS or not.

The second and third value relevance metrics are the $\mathrm{R}^{2}$ value from the regression given by:

$[\mathrm{EPS} / \mathrm{PRICE}]_{i t}^{*}=\Omega_{0}+\Omega_{l} \mathrm{RETURN}_{i t}+\sum_{j=2}^{n} \Omega_{j} X_{i, t}+\Omega_{n}$ DummyYear $+\varepsilon_{t}$

Where, [EPS/PRICE] is the earning per share divided by stock price three months after fiscal year end of firm i; [EPS/PRICE]* is the residual of regression of EPS/PRICE on country fixed effect. RETURN is stock return of bank $\mathrm{i}$ three months after fiscal year-end $t: \operatorname{Ln}\left(\mathrm{P}_{t} / \mathrm{P}_{\mathrm{t}-1}\right)$ (Barth et al., 2008; Manganaris et al., 2015); $\mathrm{X}_{\mathrm{it}}$ are the control variables.

The difference in the quality of information is more pronounced for bad news (in case of negative stock RETURN), than for good news (in case of positive stock RETURN) (Ball et al., 2000; Barth 
et al., 2008). In fact, poor stock market returns could increase the incentive to manage earnings. Thus, we estimate two models with EPS depending on whether the stock market return (Eq 6) is positive or negative. To obtain good and bad news value relevance metrics that unaffected by mean difference across countries, we first regress EPS divided by stock price (EPS/PRICE) on country fixed effect. Then, in a second step, the residuals from this regression (EPS/PRICE) ${ }^{*}$ are regressed on stock return (RETURN) separately for each category of banks for good and bad news. Empirically, accounting income should exhibit higher $\mathrm{R}^{2} \mathrm{~s}$ for bad news than for positive (Ball et al., 2000).

\subsection{Robustness results}

The table 8 presents robustness of relevance of accounting numbers (EPS and BVPS) for the different category of banks with considering the adoption of IFRS or not (See Eq 5).

For IBs, our results show a higher level of adjusted $R^{2}$ for banks applying IFRS (adj $R^{2}=42.7 \%$ ) compared to those not applying IFRS ( $\operatorname{adj} \mathrm{R}^{2}=26.4 \%$ ). We report also a higher coefficient of EPS (13.80) for IBs adopting IFRS (Column 3). IFRS therefore improves the accounting information of IBs. Results are also evidencing an improvement in the adjusted $\mathrm{R}^{2}$ for HBs applying IFRS (adj $\left.\mathrm{R}^{2}=70.1 \%\right)$.

With regards to CBs, while the adjusted $R^{2}$ for banks not applying IFRS ( $\operatorname{adj} R^{2}=64.3$ ) is higher than those applying IFRS (adj R2=41.1\%), but the EPS coefficient (7.64) is higher for CBs applying IFRS (versus 6.02 for those not adopting IFRS). Even if the latter results are a little mixed, we can still conclude that banks' accounting information applying IFRS, and more specifically, IBs and HBs, has improved. According to Ball et al. (2003), even if companies applying IFRS, which are higher quality standards, the effects of the financial reporting system's features, other than the standards themselves, could eliminate any improvement in accounting quality arising from adopting IFRS. A lax application of IFRS standards in CBs compared to banks offering Islamic financial services (IBs and HBs) may lead to limited compliance with the standards, thus limiting their effectiveness (Ball et al., 2003).

(Insert Table 8) 
Table 9 presents the results for the second model of robustness (See Eq 6). The second and third robustness value relevance metrics, for bad news and good news, respectively, show higher $\mathrm{R}^{2}$ for bad news (12\%) for IBs, compared to good news $(11 \%)$. The same result is found for HBs where $\mathrm{R}^{2}$ values are $25 \%$ and $23 \%$ for bad and good news, respectively. The results are different for $\mathrm{CBs}$, where the $\mathrm{R}^{2}$ for good news (40\%) is much higher than for bad news (4\%). According to Ball et al. (2000, p.21) “...reversing bad investment decisions and strategies is personally more costly to managers than continuing good ones... We therefore expect accounting income to be asymmetrically conservative in all countries". Ball et al. (2000) assume that empirically, accounting information should exhibit higher $\mathrm{R}^{2}$ for bad news than for good news. Based on Ball et al. (2000) analysis, we therefore, highlight the conservatism behavior adopted by IBs and HBs. Opportunity and conservatism combined capture much of the commonly used concept of "financial disclosure \& transparency" for banks offering Islamic financial services. "Transparency is defined as the ability of users to see through the financial statements to comprehend the underlying accounting events and transactions in the firm" (Ball et al., 2003, p. 237). Our results show that IBs and HBs, through "timely recognition of unrealized losses" by integrated bad news, reduces asymmetry and become more transparent than CBs. The study of Ball et al. (2003) shows that Asian firms "timely loss recognition" is not better than it is for firms in code law countries. "Accounting standards and preparer incentives in these countries interact to produce generally low quality financial reporting, consistent with the hypothesis that reporting quality ultimately is determined by the underlying economic and political factors influencing managers' and auditors' incentives, and not by accounting standards"(Ball et al., 2003, p.236). Therefore, there is a significant contribution of compliance with Islamic Finance rules in IBs and HBs that substantially reduces managers' opportunistic behavior to manage earnings, which can lead to relevant accounting information.

(Insert Table 9)

\section{Conclusion}

The purpose of this study is to investigate the relevance of the accounting numbers of banks with particular attention to banks following Islamic finance ethics with considering the 
international standards IFRS and AAOIFI. The panel is composed of 201 listed banks from 14 countries over the period 2010-2018.

The results show that the earnings per share (EPS) and book value of equity per share $(B V P S)$ are generally relevant for all banks and that this relevance is higher for IBs and HBs, compared to CBs. Besides, we provide evidence on the moderation effect of IFRS and AAOIFI on the relevance of the accounting information in IBs. Our findings support the notion that religiosity tends to reduce unethical activities by managers and function as an alternative control mechanism for disclosing reliable information.

Our findings offer a number of practical implications. Apart from highlighting the usefulness of bank accounting information helping investors in financial markets to make investment decisions, the study is useful for investors who consider Islamic ethical practices when making their investment decisions. Our study puts into perspective that compliance with Islamic finance ethics would bring confidence to the general public and the financial markets regarding the credibility of Islamic banks. Our findings also highlight challenges facing AAOIFI initiative to bring public confidence. Therefore, strengthening collaboration between regulators and AAOIFI is required. Such cooperation will create an enabling environment for investors for their decisionmaking process.

One limitation of our research is the reduced number of sampled listed IBs since we deleted countries that do not have both listed Islamic and conventional banks. Furthermore, we did not take into consideration corporate governance characteristics in the current research due to data availability. Future research could investigate the moderating role of corporate governance on the value relevance of accounting information in IBs.

\section{References}

AAOIFI-GS2. (2015), "Shari 'a Review (Governance Standard for Islamic Financial Institutions No.2)”, Accounting Auditing and Governance Standards. 
Abdelsalam, O., Dimitropoulos, P., Elnahass, M. and Leventis, S. (2016), "Earnings management behaviors under different monitoring mechanisms: The case of Islamic and conventional banks", Journal of Economic Behavior \& Organization, Elsevier B.V., Vol. 132, pp. 155-173.

Abdelsalam, O., Chantziaras, A., Omoteso, K., \& Ibrahim, M. (2020), "The impact of religiosity on earnings quality: International evidence from the banking sector", The British Accounting Review, In Press.

Abdul-Baki, Z., Bukola Uthman, A., Aliu Olanrewaju, A. and Aramide Ibrahim, S. (2013), "Islamic perspective of management accounting decision making techniques", Journal of Islamic Accounting and Business Research, Vol. 4 No. 2, pp. 203-219.

Abdullah, W.A.W., Percy, M. and Stewart, J. (2015), "Determinants of voluntary corporate governance disclosure: Evidence from Islamic banks in the Southeast Asian and the Gulf Cooperation Council regions”, Journal of Contemporary Accounting and Economics, Vol. 11 No. 3, pp. 262-279.

Abuzayed, B., Molyneux, P. and Al-Fayoumi, N. (2009), "Market value, book value and earnings: is bank efficiency a missing link?", Managerial Finance, Vol. 35 No. 2, pp. 156-179.

Agostino, M., Drago, D. and Silipo, D.B. (2011), "The value relevance of IFRS in the European banking industry", Review of Quantitative Finance and Accounting, Vol. 36 No. 3, pp. 437-457.

Ahmad, I. (2006), "Is economic value added more associated with stock return than accounting earnings? The UK evidence", International Journal of Managerial Finance, Vol. 2 No. 4, pp. 343-353.

Aiken, L.S. and West, S.G. (1991), "Multiple Regression Testing and Interpreting Interactions", SAGE PUBLISHING.

Alali, F.A. and Foote, P.S. (2012), "The value relevance of international financial reporting standards: Empirical evidence in an emerging market", The International Journal of Accounting, Vol. 47 No. 1, pp. 85-108.

Al-Hares, O.M., AbuGhazaleh, N.M. and Haddad, A.E. (2012), "Value relevance of earnings, book value and dividends in an emerging capital market: Kuwait evidence”, Global Finance Journal, Vol. 23 No. 3, pp. 221-234.

Almutairi, A.R. and Quttainah, M.A. (2017), “Corporate governance: evidence from Islamic banks”, Social Responsibility Journal, Vol 13, No. 3, pp. 601-624.

Amir, E., Harris, T.S. and Venuti, E.K. (1993), “A comparison of the value-relevance of U.S. versus NonU.S. GAAP accounting measures using Form 20-F reconciliations", Journal of Accounting Research, Vol. 31 No. 3, pp. 230-264.

Anandarajan, A., Francis, B., Hasan, I. and John, K. (2011), "Value relevance of banks: global evidence”, Review of Quantitative Finance and Accounting, Vol. 36 No. 1, pp. 33-55.

Ball, R. and Brown, P. (1968), “An empirical evaluation of accounting income numbers", Journal of Accounting Research, Vol. 6 No. 2, pp. 159-178. 
Ball, R., Kothari, S. P., \& Robin, A. (2000), "The effect of international institutional factors on properties of accounting earnings". Journal of Accounting and Economics, Vol. 29 No. 1, pp. 1-51

Ball, R., Robin, A., \& Wu, J. S. (2003), "Incentives versus standards: properties of accounting income in four East Asian countries", Journal of Accounting and Economics, Vol. 36 No. 1-3, pp. 235-270.

Baron, R.M. and Kenny, D.A. (1986), “The moderator-mediator variable distinction in social psychological research - Conceptual, strategic, and statistical considerations", Journal of Personality and Social Psychology, Vol. 51 No. 6, pp. 1173-1182.

Barth, M.E., Beaver, W.H. and Landsman, W.R. (1996), "Value-relevance of banks' fair value disclosures under SFAS No. 107”, The Accounting Review, Vol. 71 No. 4, pp. 513-537.

Barth, M. E., Landsman, W. R., \& Lang, M. H. (2008). "International accounting standards and accounting quality", Journal of accounting research, Vol. 46 No. 3, pp. 467-498.

Basiruddin, R. and Ahmed, H. (2019), "Corporate governance and shariah noncompliant risk in Islamic banks : Evidence from Indonesia and Malaysia", Corporate Governance, pp. 1-24.

Beekun, R.I. and Badawi, J.A. (2005), "Balancing ethical responsibility among multiple organizational stakeholders: The Islamic perspective", Journal of Business Ethics, Vol. 60 No. 2, pp. 131-145.

Brief, P., Dukerich, J.M., Brown, P.R. and Brett, J.F. (1996), "What's wrong with the treadway commission report? Experimental analyses of the effects of personal values and codes of conduct on fraudulent financial reporting”, Journal of Business Ethics, Vol. 15 No. 2, pp. 183-198.

Burke, Q.L. and Wieland, M.M. (2017), "Value relevance of banks' cash flows from operations”, Advances in Accounting Journal, Vol. 39 No. 60-78.

Collins, D.W., Maydew, E.L. and Weiss, I.S. (1997), "Changes in the value-relevance of earnings and book values over the past forty years", Journal of Accounting \& Economics, Vol. 24 No. 1, pp. 39-67.

Cornett, M.M., McNutt, J.J. and Tehranian, H. (2009), “Corporate governance and earnings management at large US bank holding companies”, Journal of Corporate Finance, Vol. 15 No. 4, pp. 412-430.

Dhaliwal, D., Subramanyam, K.R. and Trezevant, R. (1999), "Is comprehensive income superior to net income as a measure of firm performance?", Journal of Accounting \& Economics, Vol. 26 No. 13, pp. 43-67.

Dimitropoulos, P.E., Asteriou, D. and Koumanakos, E. (2010), “The relevance of earnings and cash flows in a heavily regulated industry: Evidence from the Greek banking sector", Advances in Accounting, Vol. 26 No. 2, pp. 290-303.

Dimitropoulos, P.E., Asteriou, D., Kousenidis, D. and Leventis, S. (2013), "The impact of IFRS on accounting quality: Evidence from Greece”, Advances in Accounting, Vol. 29 No. 1, pp. 108-123.

Dumontier, P. and Labelle, R. (1998), “Accounting earnings and firm valuation: the French case”, European Accounting Review, Vol. 7 No. 2, pp. 163-183. 
Dumontier, P. and Raffournier, B. (1999), "Vingt ans de recherche positive en comptabilité financière", Comptabilité Contrôle Audit, Vol. numero spe, pp. 179-197.

Dumontier, P. and Raffournier, B. (2002). "Accounting and capital markets: a survey of the European evidence”. European Accounting Review, Vol. 11 No. 1, pp. 119-151.

Dyreng, S.D., Mayew, W.J. and Williams, C.D. (2012), "Religious social norms and corporate financial reporting", Journal of Business Finance and Accounting, Vol. 39 No. 7-8, pp. 845-875.

Eccher, E.A., Ramesh, K. and Thiagarajan, S.R. (1996), "Fair value disclosures by bank holding companies", Conference Issue on Contemporary Financial Reporting Issues, Vol. 22 No. 1, pp. 79 117.

Elnahass, M., Izzeldin, M. and Steele, G. (2018), "Capital and earnings management: Evidence from alternative banking business models", International Journal of Accounting, Vol. 53 No. 1, pp. 20 32.

Farag, H., Mallin, C. and Ow-Yong, K. (2017), "Corporate governance in Islamic banks: New insights for dual board structure and agency relationships", Journal of International Financial Markets, Institutions and Money, Vol. 54, pp. 59-77.

Feltham, G.A. and Ohlson, J.A. (1995), "Valuation and clean surplus accounting for operating and financial activities", Contemporary Accounting Research, Vol. 11 No. 2, pp. 689-731.

Fields, T.D., Rangan, S. and Ramu Thiagarajan, S. (1998), “An empirical evaluation of the usefulness of Non-GAAP accounting measures in the real estate investment trust industry", Review of Accounting Studies, Vol. 3 No. 1/2, pp. 103-130.

Grais, W. and Pellegrini, M. (2006), “Corporate governance and stakeholders' financial interests in institutions offering financial services". https://openknowledge.worldbank.org/handle/10986/9028

Haniffa, R. and Hudaib, M. (2007), "Exploring the ethical identity of Islamic banks via communication in annual reports", Journal of Business Ethics, Vol. 76 No. 1, pp. 97-116.

Harris, T.S., Lang, M. and Peter Möller, H. (1994), “The value relevance of German accounting measures: An empirical analysis", Journal of Accounting Research, Vol. 32 No. 2, pp. 187-209.

Hassan, M.K., Aliyu, S., Huda, M. and Rashid, M. (2019), “A survey on Islamic Finance and accounting standards", Borsa Istanbul Review, Vol. 19, pp. S1-S13.

Helm, R. and Mark, A. (2012), "Analysis and evaluation of moderator effects in regression models: State of art, alternatives and empirical example”, Review of Managerial Science, Vol. 6 No. 4, pp. $307-$ 332.

Holthausen, R.W. and Watts, R.L. (2001), "The relevance of the value-relevance literature for financial accounting standard setting", Journal of Accounting \& Economics, Vol. 31 No. 1-3, pp. 3-75. 
IASB. (2008), "Exposure Draft: Conceptual Framework for Improved Financial Information”, in IASB (Ed.), .

IASB. (2010), "Conceptual Framework for Financial Reporting", presented at the Exposure Draft ED/2010/2 UK: International Accounting Standards Board.

Kadri, M.H. (2016), "Value relevance of book value and earnings: a comparison between Islamic and conventional banks in Malaysia.", Malaysian Accounting Review, Vol. 15 No. 2.

Kamla, R. (2009), "Critical insights into contemporary Islamic accounting", Critical Perspectives on Accounting, Vol. 20 No. 8, pp. 921-932.

Kamla, R. and Haque, F. (2017), "Islamic accounting, neo-imperialism and identity staging: The Accounting and Auditing Organization for Islamic Financial Institutions", Critical Perspectives on Accounting, pp. 1-20.

Kamla, R. and Rammal, H.G. (2013), "Social reporting by Islamic banks: does social justice matter?”, Accounting, Auditing \& Accountability Journal, Vol. 26 No. 6, pp. 911-945.

Keener, M.H. (2011), "The relative value relevance of earnings and book value across industries", Journal of Finance \& Accountancy, Vol. 6, pp. 1-19.

Kim, O. (2013), "Russian accounting system: Value relevance of reported information and the IFRS adoption perspective", The International Journal of Accounting, Vol. 48 No. 4, pp. 525-547.

Kothari, S.P. and Zimmerman, J.L. (1995), "Price and return models", Journal of Accounting \& Economics, Vol. 20 No. 2, pp. 155-192.

Lassoued, N., Attia, M.B.R. and Sassi, H. (2018), "Earnings management in islamic and conventional banks: Does ownership structure matter? Evidence from the MENA region", Journal of International Accounting, Auditing and Taxation, Vol. 30 December, pp. 85-105.

Lee, H.-L. and Lee, H. (2013), "Do Big 4 audit firms improve the value relevance of earnings and equity?", Managerial Auditing Journal, Vol. 28 No. 7, pp. 628-646.

Lenormand, G. and Touchais, L. (2009), “Les IFRS améliorent-elles la qualité de l'information financière ? Approche par la value relevance”, Comptabilité-Contrôle-Audit, Vol. 15 No. 2, pp. 145-163.

Leventis, S., Dimitropoulos, P.E. and Anandarajan, A. (2011), "Loan loss provisions, earnings management and capital management under IFRS: The case of EU commercial banks", Journal of Financial Services Research, Vol. 40 No. 1, pp. 103-122.

Leventis, S. and Dimitropoulos, P. (2012), "The role of corporate governance in earnings management: experience from US banks", Journal of Applied Accounting Research, Vol. 13 No. 2, pp. 161-177.

Lewis, K.M. (2006), "Islam and accounting. Accounting Forum, Vol. 25 No. 2, pp. 103-127. 
Manganaris, P., Spathis, C. and Dasilas, A. (2015), "The effects of mandatory IFRS adoption and conditional conservatism on European bank values", Journal of International Accounting, Auditing and Taxation, Vol. 24, pp. 72-81.

Manganaris, P., Spathis, C. and Dasilas, A. (2016), "How institutional factors and IFRS affect the value relevance of conservative and non-conservative banks", Journal of Applied Accounting Research. Vol 17, No. 2, pp. 211-236.

Martinez, I. (2004), "Le contenu informatif des chiffres comptables: vers de nouvelles améliorations méthodologiques?", Comptabilité Contrôle Audit, Vol. 10 No. 2, pp. 9-30.

Maurer, B. (2002), “Anthropological and accounting knowledge in Islamic banking and finance : Rethinking critical accounts", The Journal of the Royal Anthropological Institute, Vol. 8 No. 4, pp. 645-667.

Mukhlisin, M. (2016), "How ethical are financial reporting standards for Islamic financial institutions?", presented at the the annual British Accounting and Finance Association (BAFA), Bath, UK.

Nelson, K.K. (1996), "Fair value accounting for commercial banks: An empirical analysis of SFAS No. 107”, Accounting Review, Vol. 71 No. 2, pp. 161-182.

Nienhaus, V. (2011), "Islamic finance ethics and Shari'ah law in the aftermath of the crisis: Concept and practice of Shari'ah compliant finance", Ethical Perspectives, Vol. 18 No. 4, pp. 591-623.

Ohlson, J.A. (1995), “Earnings, book values, and dividends in equity valuation”, Contemporary Accounting Research, Vol. 11 No. 2, pp. 661-687.

Papadamou, S. and Tzivinikos, T. (2013), "The risk relevance of International Financial Reporting Standards: Evidence from Greek banks", International Review of Financial Analysis, Vol. 27, pp. 43-54.

Qu, X. and Zhang, G. (2015), "Value-relevance of earnings and book value over the institutional transition in China: The suitability of fair value accounting in this emerging market", The International Journal of Accounting, Vol. 50 No. 2, pp. 195-223.

Safieddine, A. (2009), "Islamic financial institutions and corporate governance: New insights for agency theory", Corporate Governance, Vol. 17 No. 2, pp. 142-158.

Tahat, Y. A., \& Alhadab, M. (2017), "Have accounting numbers lost their value relevance during the recent financial credit crisis?", The Quarterly Review of Economics and Finance, Vol. 66, pp.182-191.

Toumi, K., Louhichi, W. and Viviani, J.-L. (2012), “Alternative financial decision principles: Theoretical foundations of Islamic banks' capital structure”, In Recent Developments in Alternative Finance: Empirical Assessments and Economic Implications, (International Symposia in Economic Theory and Econometrics, Volume 22). William A. Barnett, Fredj Jawadi (Ed.) Emerald Group Publishing Limited, Vol. 22, pp. 157-172. 
Venkatachalam, M. (1996), "Value-relevance of banks' derivatives disclosures", Journal of Accounting \& Economics, Vol. 22 No. 1-3, pp. 327-355.

Weaver and Agle. (2002), "Religiosity and ethical behaviour in organizations: a symbolic interactionist perspective.", The Academy of Management Review, Vol. 27, pp. 77-97. 


\begin{tabular}{|c|c|c|c|c|}
\hline COUNTRY & $\begin{array}{c}\text { Panel A: } \\
\text { Full sample }\end{array}$ & $\begin{array}{c}\text { Panel B: } \\
\text { Sub-sample of } \\
\text { conventional banks } \\
\text { (CBs) }\end{array}$ & $\begin{array}{c}\text { Panel C: } \\
\text { Sub-sample of } \\
\text { Islamic banks (IBs) }\end{array}$ & $\begin{array}{c}\text { Panel D: } \\
\text { Hybrid Banks (HBs) }\end{array}$ \\
\hline BAHRAIN & 11 & 3 & 6 & 2 \\
\hline BANGLADESH & 31 & 14 & 8 & 9 \\
\hline EGYPT & 13 & 8 & 3 & 2 \\
\hline INDONESIA & 30 & 27 & 1 & 2 \\
\hline IRAQ & 11 & 8 & 3 & 0 \\
\hline JORDAN & 12 & 10 & 2 & 0 \\
\hline KUWAIT & 9 & 4 & 4 & 1 \\
\hline MALAYSIA & 9 & 3 & 1 & 5 \\
\hline OMAN & 6 & 3 & 1 & 2 \\
\hline PAKISTAN & 19 & 10 & 3 & 6 \\
\hline QATAR & 8 & 3 & 3 & 2 \\
\hline SAUDI ARABIA & 12 & 4 & 4 & 4 \\
\hline $\begin{array}{l}\text { SYRIAN ARAB } \\
\text { REPUBLIC }\end{array}$ & 9 & 8 & 1 & 0 \\
\hline $\begin{array}{l}\text { UNITED ARAB } \\
\text { EMIRATES }\end{array}$ & 21 & 7 & 7 & 7 \\
\hline TOTAL & 201 & 112 & 47 & 42 \\
\hline
\end{tabular}




\begin{tabular}{|c|c|c|c|}
\hline Variable & Notation & Description & Source \\
\hline Price & $P R I C E_{i t}$ & $\begin{array}{l}\text { Price of a share of bank i three months after fiscal } \\
\text { year-end } t \text { in US } \$\end{array}$ & $\begin{array}{l}\text { Thomson Reuters } \\
\text { database }\end{array}$ \\
\hline Return & $R E T U R N_{i t}$ & $\begin{array}{l}\text { Stock return of bank } i \text { three months after fiscal } \\
\text { year-end } t: \operatorname{Ln}\left(\mathrm{Pt} / \mathrm{Pt} \_1\right)\end{array}$ & $\begin{array}{l}\text { Author's } \\
\text { Calculation. } \\
\text { Thomson Reuters } \\
\text { database }\end{array}$ \\
\hline Earnings Per Share & $E P S_{i t}$ & $\begin{array}{l}\text { Earnings per share of bank i at the end of year } t \\
\text { inUS } \$\end{array}$ & $\begin{array}{l}\text { Thomson Reuters } \\
\text { database }\end{array}$ \\
\hline Book Value Per Share & $B V P S_{i t}$ & $\begin{array}{l}\text { Book value per share of bank i at the end of year } t \\
\text { in US \$ }\end{array}$ & $\begin{array}{l}\text { Thomson Reuters } \\
\text { database }\end{array}$ \\
\hline SIZE & $S I Z E_{i t}$ & $\begin{array}{l}\text { Ln of bank market value (MV) three months after } \\
\text { fiscal year-end } t: \operatorname{Ln} \text { (Market value) }\end{array}$ & $\begin{array}{l}\text { Thomson Reuters } \\
\text { database }\end{array}$ \\
\hline $\begin{array}{l}\text { International Financial } \\
\text { Reporting Standards }\end{array}$ & IFRS $_{t}$ & $\begin{array}{l}\text { Dummy variable equal to } 1 \text { if the bank considers } \\
\text { IFRS at time t, } 0 \text { otherwise }\end{array}$ & $\begin{array}{l}\text { Thomson Reuters } \\
\text { database }\end{array}$ \\
\hline $\begin{array}{l}\text { Mandatory AAOIFI } \\
\text { accounting standards }\end{array}$ & $A A O I F I_{t}$ & $\begin{array}{l}\text { Dummy variable that takes } 1 \text { if the country requires } \\
\text { compliance with AAOIFI "accounting" standards for } \\
\text { banks offering Islamic financial services (if relevant } \\
\text { standards exist), } 0 \text { otherwise. }\end{array}$ & $\begin{array}{l}\text { Central banks } \\
\text { AAOIFI }\end{array}$ \\
\hline $\begin{array}{l}\text { Regulatory Pillar } 3 \\
\text { disclosure } \\
\text { requirements }\end{array}$ & PIL $_{t}$ & $\begin{array}{l}\text { Dummy variable that takes } 1 \text { if the supervisor in a } \\
\text { given country requires banks the implementation of } \\
\text { Basel II guidelines - Pillar } 3 \text { disclosure requirements, } \\
0 \text { otherwise }\end{array}$ & $\begin{array}{l}\text { Central banks } \\
\text { BIS, FSI Survey : } \\
\text { Basel II, } 2.5 \text { and III } \\
\text { Implementation }\end{array}$ \\
\hline $\begin{array}{l}\text { Stock Market } \\
\text { Capitalization to GDP } \\
\text { Ratio }\end{array}$ & $S M C_{t}$ & $\begin{array}{l}\text { Total value of Stock Market Capitalization in } \% \text { of } \\
\text { GDP in a given country at year } t \text {. }\end{array}$ & $\begin{array}{l}\text { World Bank } \\
\text { database }\end{array}$ \\
\hline GDP growth rate & $G D P_{t}$ & $\begin{array}{l}\text { Bank i country-prevailing GDP growth rate at time } t \\
\text { in } \% \text {. }\end{array}$ & $\begin{array}{l}\text { World Bank } \\
\text { database }\end{array}$ \\
\hline Inflation rate & $I N F L_{t}$ & Bank i country inflation rate at time $t$ in $\%$ & $\begin{array}{l}\text { World Bank } \\
\text { database }\end{array}$ \\
\hline Return On Assets & $R O A_{i t}$ & Return on assets of bank $\mathrm{i}$ at the end of year $\mathrm{t}$ in $\%$ & $\begin{array}{l}\text { Thomson Reuters } \\
\text { database }\end{array}$ \\
\hline Leverage & $L E V_{i t}$ & $\begin{array}{l}\text { total debt divided by total assets at the end of year } \\
t\end{array}$ & $\begin{array}{l}\text { Thomson Reuters } \\
\text { database }\end{array}$ \\
\hline
\end{tabular}




\begin{tabular}{|c|c|c|c|c|c|}
\hline \multicolumn{5}{|c|}{ Panel A: Full Sample } & \multirow{2}{*}{$\begin{array}{c}\text { Two-sample t-tes } \\
\text { (Two-tailed) }\end{array}$} \\
\hline Variable & Mean & Std. Dev. & Min & Max & \\
\hline PRICE & 1.841 & 3.577 & 0 & 32.67 & $-1,892 * *$ \\
\hline EPS & .1052 & .172 & 0 & 1.59 & 0.475 \\
\hline BVPS & 1.171 & 2.531 & -.139 & 28.766 & $1.647^{* *}$ \\
\hline RETURN & .080 & .876 & -3.931 & 3.784 & $0,256^{*}$ \\
\hline SIZE & 6.468 & 1.744 & 1.845 & 10.416 & $-3.499 * * *$ \\
\hline AAOIFI & .313 & .463 & 0 & 1 & 0.861 \\
\hline IFRS & .508 & .500 & 0 & 1 & $-6.458 * *$ \\
\hline PIL3 & .456 & .498 & 0 & 1 & $-7.052 * * *$ \\
\hline SMC & 14.252 & 14.090 & 0 & 75.017 & $-3.695^{* *}$ \\
\hline ROA & 1.504 & 1.582 & -24.05 & 9.57 & $4.082 * * *$ \\
\hline LEV & 11.842 & 11.827 & -102.99 & 79.34 & $-6.373 * * *$ \\
\hline GDP & 4.543 & 2.758 & -4.712 & 19.592 & 0.418 \\
\hline INFLT & 4.654 & 4.576 & -2.425 & 36.702 & $3.610 * * *$ \\
\hline \multicolumn{5}{|c|}{ Panel B: Sub-sample of conventional banks (CBs) } & \\
\hline PRICE & 1.699 & 3.048 & 0 & 32.67 & \\
\hline EPS & .107 & .169 & 0 & 1.59 & \\
\hline BVPS & 1.259 & 2.627 & -.139 & 28.766 & \\
\hline RETURN & .0857 & 1.111 & -3.931 & 3.784 & \\
\hline SIZE & 6.340 & 1.836 & 1.845 & 10.397 & \\
\hline AAOIFI & .321 & .467 & 0 & 1 & \\
\hline IFRS & .441 & .496 & 0 & 1 & \\
\hline PIL3 & .383 & .486 & 0 & 1 & \\
\hline SMC & 13.133 & 11.646 & 0 & 75.017 & \\
\hline ROA & 1.647 & 1.507 & -9.91 & 9.57 & \\
\hline LEV & 10.257 & 11.787 & -102.99 & 77.22 & \\
\hline GDP & 4.568 & 2.676 & -4.712 & 19.592 & \\
\hline INFLT & 5.021 & 4.891 & -2.425 & 36.702 & \\
\hline \multicolumn{5}{|c|}{ Panel C: Sub-sample of Islamic banks (IBs) } & \\
\hline PRICE & 2.063 & 4.213 & 0 & 27.61 & \\
\hline EPS & .088 & .148 & 0 & 1.25 & \\
\hline BVPS & .790 & .971 & 0 & 5.944 & \\
\hline RETURN & .136 & .488 & -1.629 & 2.089 & \\
\hline SIZE & 6.382 & 1.587 & 2.823 & 10.416 & \\
\hline AAOIFI & .331 & .471 & 0 & 1 & \\
\hline IFRS & .671 & .470 & 0 & 1 & \\
\hline PIL3 & .569 & .495 & 0 & 1 & \\
\hline SMC & 14.248 & 15.343 & 0 & 75.017 & \\
\hline ROA & 1.155 & 2.055 & -24.05 & 8.09 & \\
\hline
\end{tabular}




\begin{tabular}{|l|c|c|c|c|}
\hline LEV & 15.111 & 14.169 & 0 & 79.34 \\
\hline GDP & 4.308 & 3.153 & -4.712 & 19.592 \\
\hline INFLT & 3.999 & 4.348 & -2.425 & 36.702 \\
\hline \multicolumn{5}{|c|}{ Panel D: Hybrid Banks (HBs) } \\
\hline PRICE & 1.973 & 4.079 & .01 & 32.67 \\
\hline EPS & .119 & .2015 & 0 & 1.59 \\
\hline BVPS & 1.348 & 3.279 & .011 & 28.766 \\
\hline RETURN & .012 & .443 & -1.252 & 1.704 \\
\hline SIZE & 6.902 & 1.588 & 3.223 & 10.199 \\
\hline AAOIFI & .269 & .444 & 0 & 1 \\
\hline IFRS & .510 & .500 & 0 & 1 \\
\hline PIL3 & .523 & .500 & 0 & 1 \\
\hline SMC & 17.419 & 17.919 & 0 & 75.017 \\
\hline ROA & 1.536 & .964 & -3.37 & 4.16 \\
\hline LEV & 12.382 & 7.399 & 0 & 43.36 \\
\hline GDP & 4.742 & 2.467 & -4.712 & 19.592 \\
\hline INFLT & 4.441 & 3.857 & -2.425 & 29.501 \\
\hline
\end{tabular}

Notes: The table 3 reports the descriptive statistics for the variables considered in our analyses. The sample period is 2010 to 2018. Panel A: results for the full sample including IBs, HBs and CBs with 1809 bank-year observations. Panel B: results for the sub-sample of CBs representing 1008 bank-year observations. Panel C: results for IBs sub-sample comprising 423 bank-year observations; Panel D: results for the sub-sample of HBs representing 378 bank-year observations; We report on the paired sample mean test $(t$-test $)$ for IBs and CB_IWs compared with sub-samples of CBs. *, **, and *** denote significance at $10 \%, 5 \%$, and 1 $\%$, respectively. $*, * *$, and $* * *$ denote significance at $10 \%, 5 \%$, and $1 \%$, respectively. Table 2 shows the variables definitions. 


\begin{tabular}{|c|c|c|c|c|c|c|c|c|c|c|}
\hline & EPS & BVPS & IFRS & SIZE & PIL3 & SMC & ROA & LEV & GDP & INFLT \\
\hline EPS & 1.0000 & & & & & & & & & \\
\hline BVPS & $0.5872 *$ & 1.0000 & & & & & & & & \\
\hline IFRS & $0.2621 *$ & $0.1778^{*}$ & 1.0000 & & & & & & & \\
\hline SIZE & $0.4223 *$ & $0.1828 *$ & $0.3217 *$ & 1.0000 & & & & & & \\
\hline PIL3 & 0.2553* & $0.1691 *$ & $0.2652 *$ & $0.1764 *$ & 1.0000 & & & & & \\
\hline SMC & 0.3804* & $0.2134 *$ & $0.2284 *$ & $0.4240^{*}$ & $0.2800^{*}$ & 1.0000 & & & & \\
\hline ROA & 0.1497* & $0.0930 *$ & $0.1043^{*}$ & $0.2462 *$ & $0.1190 *$ & $0.0714 *$ & 1.0000 & & & \\
\hline LEV & 0.0574 & 0.0245 & $0.1809 *$ & $0.1005^{*}$ & $0.1975^{*}$ & $0.0786^{*}$ & 0.0610 & 1.0000 & & \\
\hline GDP & $0.1599 *$ & $0.1229 *$ & $0.3076^{*}$ & $0.0786^{*}$ & $0.1884 *$ & 0.0470 & $0.1258 *$ & -0.0350 & 1.0000 & \\
\hline INFLT & $0.1002 *$ & 0.0285 & $0.4278 *$ & $0.3324^{*}$ & $0.1348 *$ & $0.1868 *$ & $0.0656^{*}$ & $-0.1810^{*}$ & 0.0440 & 1.0000 \\
\hline
\end{tabular}


Table 5 : Value relevance of accounting numbers for banks. Period: $2010-2018$

\begin{tabular}{|c|c|c|c|c|c|c|c|c|c|c|c|c|c|}
\hline & & \multicolumn{3}{|c|}{ Panel A : Full sample } & \multicolumn{3}{|c|}{ Panel B : Sub-sample CBs } & \multicolumn{3}{|c|}{ Panel C : Sub-sample IBs } & \multicolumn{3}{|c|}{ Panel D : Sub-sample HBs } \\
\hline & & (1) & (2) & (3) & (4) & (5) & (6) & (7) & $(8)$ & (9) & (10) & (11) & (12) \\
\hline VARIABLES & & PRICE & PRICE & PRICE & PRICE & PRICE & PRICE & PRICE & PRICE & PRICE & PRICE & PRICE & PRICE \\
\hline EPS & & $\begin{array}{c}5.62 * * * \\
(0.54)\end{array}$ & & $\begin{array}{c}4.44 * * * \\
(0.55)\end{array}$ & $\begin{array}{c}3.84 * * * \\
(0.66)\end{array}$ & & $\begin{array}{c}4.04 * * * \\
(0.64)\end{array}$ & $\begin{array}{c}5.60 * * * \\
(1.38)\end{array}$ & & $\begin{array}{c}5.07 * * * \\
(1.47)\end{array}$ & $\begin{array}{c}14.80 * * * \\
(0.98)\end{array}$ & & $\begin{array}{l}-0.30 \\
(1.21)\end{array}$ \\
\hline BVPS & & & $\begin{array}{c}0.40^{* * *} \\
(0.04)\end{array}$ & $\begin{array}{c}0.40 * * * \\
(0.03)\end{array}$ & & $\begin{array}{c}0.18 * * * \\
(0.04)\end{array}$ & $\begin{array}{c}0.21 * * * \\
(0.03)\end{array}$ & & $\begin{array}{c}0.75^{* *} \\
(0.34)\end{array}$ & $\begin{array}{l}0.67 * \\
(0.35)\end{array}$ & & $\begin{array}{c}1.00 * * * \\
(0.03)\end{array}$ & $\begin{array}{c}1.01 * * * * \\
(0.06)\end{array}$ \\
\hline SIZE & & $\begin{array}{c}0.37 * * * \\
(0.07)\end{array}$ & $\begin{array}{c}0.54 * * * \\
(0.07)\end{array}$ & $\begin{array}{c}0.36^{* * *} \\
(0.07)\end{array}$ & $\begin{array}{c}0.37 * * * \\
(0.07)\end{array}$ & $\begin{array}{c}0.51 * * * \\
(0.07)\end{array}$ & $\begin{array}{c}0.34 * * * \\
(0.07)\end{array}$ & $\begin{array}{c}0.50 * * * \\
(0.19)\end{array}$ & $\begin{array}{c}0.64 * * * \\
(0.20)\end{array}$ & $\begin{array}{c}0.48 * * \\
(0.20)\end{array}$ & $\begin{array}{c}0.16 \\
(0.24)\end{array}$ & $\begin{array}{c}0.32 * * \\
(0.14)\end{array}$ & $\begin{array}{c}0.33^{* *} \\
(0.15)\end{array}$ \\
\hline PIL3 & & $\begin{array}{c}-1.55 * * * \\
(0.27)\end{array}$ & $\begin{array}{c}-1.54 * * * \\
(0.26)\end{array}$ & $\begin{array}{c}-1.62 * * * \\
(0.27)\end{array}$ & $\begin{array}{c}-1.13 * * * \\
(0.37)\end{array}$ & $\begin{array}{c}-1.17 * * * \\
(0.37)\end{array}$ & $\begin{array}{c}-1.22 * * * \\
(0.39)\end{array}$ & $\begin{array}{c}-2.05 * * * \\
(0.54)\end{array}$ & $\begin{array}{c}-1.94 * * * \\
(0.54)\end{array}$ & $\begin{array}{c}-2.14 * * * \\
(0.55)\end{array}$ & $\begin{array}{c}-1.99 * * * \\
(0.66)\end{array}$ & $\begin{array}{c}-1.62 * * * \\
(0.48)\end{array}$ & $\begin{array}{c}-1.61 * * * \\
(0.48)\end{array}$ \\
\hline SMC & & $\begin{array}{c}0.03 * * * \\
(0.01)\end{array}$ & $\begin{array}{c}0.02 * * * \\
(0.01)\end{array}$ & $\begin{array}{c}0.03 * * * \\
(0.01)\end{array}$ & $\begin{array}{c}0.02 \\
(0.01)\end{array}$ & $\begin{array}{c}0.01 \\
(0.01)\end{array}$ & $\begin{array}{c}0.02 \\
(0.01)\end{array}$ & $\begin{array}{c}0.04 * * \\
(0.02)\end{array}$ & $\begin{array}{l}0.03 * \\
(0.02)\end{array}$ & $\begin{array}{c}0.04 * * \\
(0.02)\end{array}$ & $\begin{array}{c}0.03 \\
(0.02)\end{array}$ & $\begin{array}{l}0.03 * \\
(0.02)\end{array}$ & $\begin{array}{c}0.03 \\
(0.02)\end{array}$ \\
\hline ROA & & $\begin{array}{c}0.02 \\
(0.04)\end{array}$ & $\begin{array}{l}-0.01 \\
(0.04)\end{array}$ & $\begin{array}{l}-0.01 \\
(0.04)\end{array}$ & $\begin{array}{c}0.08 \\
(0.06)\end{array}$ & $\begin{array}{c}0.03 \\
(0.06)\end{array}$ & $\begin{array}{c}0.06 \\
(0.06)\end{array}$ & $\begin{array}{l}-0.04 \\
(0.06)\end{array}$ & $\begin{array}{l}-0.02 \\
(0.06)\end{array}$ & $\begin{array}{l}-0.05 \\
(0.06)\end{array}$ & $\begin{array}{l}-0.11 \\
(0.21)\end{array}$ & $\begin{array}{c}0.04 \\
(0.15)\end{array}$ & $\begin{array}{c}0.04 \\
(0.15)\end{array}$ \\
\hline LEV & & $\begin{array}{l}-0.01 \\
(0.01)\end{array}$ & $\begin{array}{l}-0.01 \\
(0.01)\end{array}$ & $\begin{array}{l}-0.01 \\
(0.01)\end{array}$ & $\begin{array}{l}-0.03 * \\
(0.01)\end{array}$ & $\begin{array}{l}-0.02 * \\
(0.01)\end{array}$ & $\begin{array}{c}-0.03 * * \\
(0.01)\end{array}$ & $\begin{array}{c}0.00 \\
(0.01)\end{array}$ & $\begin{array}{l}-0.00 \\
(0.01)\end{array}$ & $\begin{array}{l}-0.00 \\
(0.01)\end{array}$ & $\begin{array}{l}-0.00 \\
(0.03)\end{array}$ & $\begin{array}{l}-0.02 \\
(0.02)\end{array}$ & $\begin{array}{l}-0.02 \\
(0.02)\end{array}$ \\
\hline GDP & & $\begin{array}{c}0.11^{* * * *} \\
(0.02)\end{array}$ & $\begin{array}{c}0.10^{* * * *} \\
(0.02)\end{array}$ & $\begin{array}{c}0.11^{* * *} \\
(0.02)\end{array}$ & $\begin{array}{c}0.10^{* * *} \\
(0.03)\end{array}$ & $\begin{array}{c}0.09 * * * \\
(0.03)\end{array}$ & $\begin{array}{c}0.10^{* * *} \\
(0.03)\end{array}$ & $\begin{array}{l}0.11^{* *} \\
(0.04)\end{array}$ & $\begin{array}{c}0.10 * * \\
(0.04)\end{array}$ & $\begin{array}{l}0.10 * * \\
(0.04)\end{array}$ & $\begin{array}{c}0.15 * * \\
(0.07)\end{array}$ & $\begin{array}{c}0.12 * * \\
(0.05)\end{array}$ & $\begin{array}{c}0.12 * * \\
(0.05)\end{array}$ \\
\hline INFLT & & $\begin{array}{c}0.02 \\
(0.02)\end{array}$ & $\begin{array}{c}0.01 \\
(0.02)\end{array}$ & $\begin{array}{c}0.02 \\
(0.02)\end{array}$ & $\begin{array}{c}0.01 \\
(0.03)\end{array}$ & $\begin{array}{c}0.01 \\
(0.03)\end{array}$ & $\begin{array}{c}0.01 \\
(0.03)\end{array}$ & $\begin{array}{c}0.00 \\
(0.05)\end{array}$ & $\begin{array}{c}0.01 \\
(0.05)\end{array}$ & $\begin{array}{c}0.01 \\
(0.05)\end{array}$ & $\begin{array}{l}0.10^{*} \\
(0.06)\end{array}$ & $\begin{array}{l}0.08^{*} \\
(0.04)\end{array}$ & $\begin{array}{l}0.08^{*} \\
(0.04)\end{array}$ \\
\hline Constant & & $\begin{array}{l}-1.03 \\
(0.67)\end{array}$ & $\begin{array}{c}-1.95 * * * \\
(0.69)\end{array}$ & $\begin{array}{l}-0.94 \\
(0.61)\end{array}$ & $\begin{array}{l}-0.73 \\
(0.90)\end{array}$ & $\begin{array}{l}-1.16 \\
(0.95)\end{array}$ & $\begin{array}{l}-0.48 \\
(0.81)\end{array}$ & $\begin{array}{l}-1.43 \\
(1.37)\end{array}$ & $\begin{array}{l}-2.44^{*} \\
(1.46)\end{array}$ & $\begin{array}{l}-1.32 \\
(1.40)\end{array}$ & $\begin{array}{l}-0.49 \\
(2.21)\end{array}$ & $\begin{array}{l}-1.32 \\
(1.39)\end{array}$ & $\begin{array}{l}-1.38 \\
(1.42)\end{array}$ \\
\hline Observations & & 1,361 & 1,354 & 1,347 & 738 & 742 & 735 & 336 & 325 & 325 & 287 & 287 & 287 \\
\hline Year dummy & & Yes & Yes & Yes & Yes & Yes & Yes & Yes & Yes & Yes & Yes & Yes & Yes \\
\hline Country_Fixed & & Yes & Yes & Yes & Yes & Yes & Yes & Yes & Yes & Yes & Yes & Yes & Yes \\
\hline $\mathrm{R}_{-}^{2} \mathrm{O}$ & & 0.552 & 0.580 & 0.635 & 0.537 & 0.534 & 0.575 & 0.662 & 0.633 & 0.678 & 0.716 & 0.860 & 0.860 \\
\hline Cchi2 & & $824.8 * * *$ & $735.3 * * *$ & $1291 * * *$ & $503.2 * * *$ & $424.0 * * *$ & $770.1 * * *$ & $267.2 * * *$ & $194.9 * * *$ & $290.8 * * *$ & $434.5^{* * *}$ & $1594 * * *$ & $1588 * * *$ \\
\hline $\begin{array}{l}\text { Breusch-Pagam } \\
\text { test }\end{array}$ & $\begin{array}{c}\text { Chibar2 } \\
\text { Prob>Chibar2 }\end{array}$ & $\begin{array}{c}349.92 \\
0.000\end{array}$ & $\begin{array}{c}515.31 \\
0.000\end{array}$ & $\begin{array}{c}173.82 \\
0.000\end{array}$ & $\begin{array}{c}117.84 \\
0.000\end{array}$ & $\begin{array}{c}132.53 \\
0.000\end{array}$ & $\begin{array}{l}39.48 \\
0.000\end{array}$ & $\begin{array}{l}55.97 \\
0.000\end{array}$ & $\begin{array}{l}83.89 \\
0.000\end{array}$ & $\begin{array}{l}32.52 \\
0.000\end{array}$ & $\begin{array}{c}6.55 \\
0.005\end{array}$ & $\begin{array}{c}6.32 \\
0.005\end{array}$ & $\begin{array}{c}6.33 \\
0.005\end{array}$ \\
\hline
\end{tabular}

Breusch and Pagan Lagrangian multiplier test for random effects reject the null hypothesis and conclude random effects is appropriate after Hausmann test, Standard errors in parentheses; $* * * \mathrm{p}<0.01, * * \mathrm{p}<0.05, * \mathrm{p}<0.1$. Table 2 shows the variables definitions. 
Table 6 : Moderation effect of IFRS on value relevance of accounting numbers for banks. Period: 2010-2018

\begin{tabular}{|c|c|c|c|c|c|c|c|c|c|}
\hline & & \multicolumn{2}{|c|}{ Panel A : Full sample } & \multicolumn{2}{|c|}{ Panel B : Sub-sample CBs } & \multicolumn{2}{|c|}{ Panel C : Sub-sample IBs } & \multicolumn{2}{|c|}{ Panel D : Sub-sample HB } \\
\hline VARIABLES & & $\begin{array}{c}(1) \\
\text { PRICE }\end{array}$ & $\begin{array}{c}(2) \\
\text { PRICE }\end{array}$ & $\begin{array}{c}(3) \\
\text { PRICE }\end{array}$ & $\begin{array}{c}(4) \\
\text { PRICE }\end{array}$ & $\begin{array}{c}(5) \\
\text { PRICE }\end{array}$ & $\begin{array}{c}(6) \\
\text { PRICE }\end{array}$ & $\begin{array}{c}(7) \\
\text { PRICE }\end{array}$ & $\begin{array}{c}(8) \\
\text { PRICE }\end{array}$ \\
\hline EPS & & $\begin{array}{c}4.43 * * * \\
(0.55)\end{array}$ & $\begin{array}{l}-0.21 \\
(0.72)\end{array}$ & $\begin{array}{c}4.00^{* * * *} \\
(0.64)\end{array}$ & $\begin{array}{l}-0.25 \\
(0.80)\end{array}$ & $\begin{array}{c}4.78 * * * \\
(1.47)\end{array}$ & $\begin{array}{c}1.14 \\
(1.79)\end{array}$ & $\begin{array}{l}-0.29 \\
(1.22)\end{array}$ & $\begin{array}{c}0.35 \\
(3.07)\end{array}$ \\
\hline BVPS & & $\begin{array}{c}0.40 * * * \\
(0.03)\end{array}$ & $\begin{array}{c}0.12 * * * \\
(0.04)\end{array}$ & $\begin{array}{c}0.21 * * * \\
(0.03)\end{array}$ & $\begin{array}{c}0.14 * * * \\
(0.04)\end{array}$ & $\begin{array}{c}0.92 * * \\
(0.37)\end{array}$ & $\begin{array}{c}0.02 \\
(0.55)\end{array}$ & $\begin{array}{c}1.01 * * * \\
(0.06)\end{array}$ & $\begin{array}{c}0.25 \\
(0.54)\end{array}$ \\
\hline IFRS & & $\begin{array}{c}0.21 \\
(0.27)\end{array}$ & $\begin{array}{c}-0.93 * * * \\
(0.28)\end{array}$ & $\begin{array}{l}-0.16 \\
(0.43)\end{array}$ & $\begin{array}{c}-1.18 * * * \\
(0.43)\end{array}$ & $\begin{array}{l}1.07 * * \\
(0.53)\end{array}$ & $\begin{array}{c}-0.39 \\
(0.81)\end{array}$ & $\begin{array}{c}0.01 \\
(0.46)\end{array}$ & $\begin{array}{l}-0.61 \\
(0.71)\end{array}$ \\
\hline EPS_IFRS & & & $\begin{array}{c}5.22 * * * \\
(1.05)\end{array}$ & & $\begin{array}{c}8.50 * * * \\
(1.39)\end{array}$ & & $\begin{array}{c}10.33 * * * \\
(2.95)\end{array}$ & & $\begin{array}{l}-0.96 \\
(3.24)\end{array}$ \\
\hline BVPS_IFRS & & & $\begin{array}{c}0.56 * * * \\
(0.07)\end{array}$ & & $\begin{array}{c}0.09 \\
(0.12)\end{array}$ & & $\begin{array}{c}0.29 \\
(0.57)\end{array}$ & & $\begin{array}{c}0.78 \\
(0.55)\end{array}$ \\
\hline SIZE & & $\begin{array}{c}0.36 * * * \\
(0.07)\end{array}$ & $\begin{array}{c}0.31 * * * \\
(0.06)\end{array}$ & $\begin{array}{c}0.34 * * * \\
(0.07)\end{array}$ & $\begin{array}{c}0.28 * * * \\
(0.06)\end{array}$ & $\begin{array}{c}0.43 * * \\
(0.20)\end{array}$ & $\begin{array}{l}0.34 * \\
(0.19)\end{array}$ & $\begin{array}{c}0.33 * * \\
(0.15)\end{array}$ & $\begin{array}{c}0.39 * * \\
(0.16)\end{array}$ \\
\hline PIL3 & & $\begin{array}{c}-1.61 * * * \\
(0.27)\end{array}$ & $\begin{array}{c}-1.52 * * * \\
(0.26)\end{array}$ & $\begin{array}{c}-1.23 * * * \\
(0.39)\end{array}$ & $\begin{array}{c}-1.29 * * * \\
(0.37)\end{array}$ & $\begin{array}{c}-2.04 * * * \\
(0.55)\end{array}$ & $\begin{array}{c}-1.87 * * * \\
(0.56)\end{array}$ & $\begin{array}{c}-1.61 * * * \\
(0.49)\end{array}$ & $\begin{array}{c}-1.59 * * * \\
(0.49)\end{array}$ \\
\hline SMC & & $\begin{array}{c}0.03 * * * \\
(0.01)\end{array}$ & $\begin{array}{c}0.03 * * * \\
(0.01)\end{array}$ & $\begin{array}{c}0.02 \\
(0.01)\end{array}$ & $\begin{array}{c}0.02 \\
(0.01)\end{array}$ & $\begin{array}{c}0.05^{* *} \\
(0.02)\end{array}$ & $\begin{array}{c}0.05^{* *} \\
(0.02)\end{array}$ & $\begin{array}{c}0.03 \\
(0.02)\end{array}$ & $\begin{array}{c}0.02 \\
(0.02)\end{array}$ \\
\hline ROA & & $\begin{array}{l}-0.01 \\
(0.04)\end{array}$ & $\begin{array}{l}-0.02 \\
(0.04)\end{array}$ & $\begin{array}{c}0.05 \\
(0.06)\end{array}$ & $\begin{array}{l}-0.02 \\
(0.06)\end{array}$ & $\begin{array}{l}-0.03 \\
(0.06)\end{array}$ & $\begin{array}{l}-0.03 \\
(0.06)\end{array}$ & $\begin{array}{c}0.04 \\
(0.15)\end{array}$ & $\begin{array}{c}0.00 \\
(0.16)\end{array}$ \\
\hline LEV & & $\begin{array}{l}-0.01 \\
(0.01)\end{array}$ & $\begin{array}{l}-0.01^{*} \\
(0.01)\end{array}$ & $\begin{array}{c}-0.03^{* *} \\
(0.01)\end{array}$ & $\begin{array}{c}-0.03 * * \\
(0.01)\end{array}$ & $\begin{array}{l}-0.00 \\
(0.01)\end{array}$ & $\begin{array}{l}-0.00 \\
(0.01)\end{array}$ & $\begin{array}{l}-0.02 \\
(0.02)\end{array}$ & $\begin{array}{l}-0.02 \\
(0.02)\end{array}$ \\
\hline GDP & & $\begin{array}{c}0.11 * * * \\
(0.02)\end{array}$ & $\begin{array}{c}0.12 * * * \\
(0.02)\end{array}$ & $\begin{array}{c}0.10 * * * \\
(0.03)\end{array}$ & $\begin{array}{c}0.12 * * * \\
(0.03)\end{array}$ & $\begin{array}{c}0.10 * * \\
(0.04)\end{array}$ & $\begin{array}{c}0.12 * * * \\
(0.05)\end{array}$ & $\begin{array}{c}0.12 * * \\
(0.05)\end{array}$ & $\begin{array}{l}0.13 * * \\
(0.05)\end{array}$ \\
\hline INFLT & & $\begin{array}{c}0.02 \\
(0.02)\end{array}$ & $\begin{array}{c}0.01 \\
(0.02)\end{array}$ & $\begin{array}{c}0.01 \\
(0.03)\end{array}$ & $\begin{array}{c}0.00 \\
(0.03)\end{array}$ & $\begin{array}{c}0.02 \\
(0.05)\end{array}$ & $\begin{array}{c}0.02 \\
(0.05)\end{array}$ & $\begin{array}{l}0.08 * \\
(0.04)\end{array}$ & $\begin{array}{c}0.06 \\
(0.04)\end{array}$ \\
\hline Constant & & $\begin{array}{l}-1.19 * \\
(0.69)\end{array}$ & $\begin{array}{c}0.04 \\
(0.65)\end{array}$ & $\begin{array}{l}-0.30 \\
(0.96)\end{array}$ & $\begin{array}{c}0.80 \\
(0.94)\end{array}$ & $\begin{array}{l}-2.22 \\
(1.47)\end{array}$ & $\begin{array}{l}-0.37 \\
(1.49)\end{array}$ & $\begin{array}{l}-1.40 \\
(1.50)\end{array}$ & $\begin{array}{l}-1.27 \\
(1.50)\end{array}$ \\
\hline Observations & & 1,347 & 1,347 & 735 & 735 & 325 & 325 & 287 & 287 \\
\hline Year dummy & & Yes & Yes & Yes & Yes & Yes & Yes & Yes & Yes \\
\hline Country_Fixed & & Yes & Yes & Yes & Yes & Yes & Yes & Yes & Yes \\
\hline $\mathrm{R}^{2} \_\mathrm{O}$ & & 0.635 & 0.677 & 0.575 & 0.609 & 0.686 & 0.720 & 0.860 & 0.861 \\
\hline Chi2 & & $1284 * * *$ & $1652 * * *$ & $759.6^{* * *}$ & $847.3^{* * *}$ & $296.3 * * *$ & $410.5^{* * *}$ & $1582 * * *$ & $1584 * * *$ \\
\hline $\begin{array}{l}\text { Breusch-Pagam } \\
\text { test }\end{array}$ & $\begin{array}{c}\text { Chibar2 } \\
\text { Prob }>\text { Chibar2 }\end{array}$ & $\begin{array}{c}173.99 \\
0.000\end{array}$ & $\begin{array}{c}176.49 \\
0.000\end{array}$ & $\begin{array}{l}39.64 \\
0.000\end{array}$ & $\begin{array}{l}49.80 \\
0.000\end{array}$ & $\begin{array}{l}28.98 \\
0.000\end{array}$ & $\begin{array}{l}12.55 \\
0.000\end{array}$ & $\begin{array}{c}9.25 \\
0.062\end{array}$ & $\begin{array}{c}9.31 \\
0.058\end{array}$ \\
\hline
\end{tabular}

Breusch and Pagan Lagrangian multiplier test for random effects reject the null hypothesis and conclude random effects is appropriate after Hausmann test, Standard errors in parentheses; $* * * \mathrm{p}<0.01, * * \mathrm{p}<0.05, * \mathrm{p}<0.1$. Table 2 shows the variables definitions. 
Table 7 : Moderation effect of AAOIFI on value relevance of accounting numbers for IBs and CBs_IWs. Period: 2010-2018

\begin{tabular}{|c|c|c|c|c|c|c|c|c|c|c|c|c|c|}
\hline \multirow[b]{3}{*}{ VARIABLES } & & \multicolumn{6}{|c|}{ Panel C: Sub-sample IBs } & \multicolumn{6}{|c|}{ Panel D : Sub-sample HBs } \\
\hline & & (1) & (2) & (3) & (4) & (5) & (6) & (7) & (8) & (9) & $(10)$ & (11) & (12) \\
\hline & & PRICE & PRICE & PRICE & PRICE & PRICE & PRICE & PRICE & PRICE & PRICE & PRICE & PRICE & PRICE \\
\hline EPS & & $\begin{array}{c}5.24 * * * \\
(1.42)\end{array}$ & $\begin{array}{c}5.63 * * * \\
(1.44)\end{array}$ & & & $\begin{array}{c}4.68 * * * * \\
(1.48)\end{array}$ & $\begin{array}{c}5.44 * * * \\
(1.47)\end{array}$ & $\begin{array}{c}13.81 * * * \\
(0.99)\end{array}$ & $\begin{array}{c}13.54 * * * \\
(1.00)\end{array}$ & & & $\begin{array}{c}0.51 \\
(1.33)\end{array}$ & $\begin{array}{l}-0.02 \\
(1.25)\end{array}$ \\
\hline BVPS & & & & $\begin{array}{c}0.98 * * * \\
(0.37)\end{array}$ & $\begin{array}{c}0.99 * * \\
(0.39)\end{array}$ & $\begin{array}{l}0.90 * * \\
(0.37)\end{array}$ & $\begin{array}{l}0.70 * \\
(0.39)\end{array}$ & & & $\begin{array}{c}0.98 * * * \\
(0.04)\end{array}$ & $\begin{array}{c}0.99 * * * \\
(0.04)\end{array}$ & $\begin{array}{c}0.96 * * * \\
(0.07)\end{array}$ & $\begin{array}{c}1.00 * * * \\
(0.07)\end{array}$ \\
\hline AAOIFI & & $\begin{array}{c}2.36^{* *} \\
(1.03)\end{array}$ & $\begin{array}{c}2.84 * * * \\
(1.07)\end{array}$ & $\begin{array}{c}2.27 * * \\
(1.12)\end{array}$ & $\begin{array}{l}2.38^{*} \\
(1.25)\end{array}$ & $\begin{array}{l}2.42 * * \\
(0.96)\end{array}$ & $\begin{array}{c}1.71 \\
(1.08)\end{array}$ & $\begin{array}{l}0.86^{*} \\
(0.52)\end{array}$ & $\begin{array}{l}-0.45 \\
(0.73)\end{array}$ & $\begin{array}{c}1.75 * * * \\
(0.37)\end{array}$ & $\begin{array}{l}1.19 * * \\
(0.50)\end{array}$ & $\begin{array}{c}1.73 * * * \\
(0.37)\end{array}$ & $\begin{array}{c}0.16 \\
(0.51)\end{array}$ \\
\hline EPS_AAOIFI & & & $\begin{array}{c}-15.67 * * * \\
(5.36)\end{array}$ & & & & $\begin{array}{c}-25.15 * * * \\
(6.55)\end{array}$ & & $\begin{array}{c}23.19 * * * \\
(8.92)\end{array}$ & & & & $\begin{array}{c}48.06 * * * * \\
(8.04)\end{array}$ \\
\hline BVPS_AAOIFI & & & & & $\begin{array}{l}-0.27 \\
(1.20)\end{array}$ & & $\begin{array}{c}3.52 * * \\
(1.39)\end{array}$ & & & & $\begin{array}{c}1.32 \\
(0.82)\end{array}$ & & $\begin{array}{c}-2.86 * * * \\
(1.04)\end{array}$ \\
\hline IFRS & & $\begin{array}{c}0.64 \\
(0.50)\end{array}$ & $\begin{array}{c}0.81 \\
(0.50)\end{array}$ & $\begin{array}{l}1.05 * * \\
(0.53)\end{array}$ & $\begin{array}{l}1.08^{*} \\
(0.56)\end{array}$ & $\begin{array}{l}1.06 * * \\
(0.53)\end{array}$ & $\begin{array}{l}0.97^{*} \\
(0.53)\end{array}$ & $\begin{array}{l}0.92^{*} \\
(0.49)\end{array}$ & $\begin{array}{l}1.11 * * \\
(0.50)\end{array}$ & $\begin{array}{c}0.98 * * * \\
(0.37)\end{array}$ & $\begin{array}{c}1.03 * * * \\
(0.37)\end{array}$ & $\begin{array}{c}0.97 * * * \\
(0.37)\end{array}$ & $\begin{array}{c}1.29 * * * \\
(0.35)\end{array}$ \\
\hline SIZE & & $\begin{array}{c}0.54 * * * \\
(0.20)\end{array}$ & $\begin{array}{c}0.62 * * * \\
(0.20)\end{array}$ & $\begin{array}{c}0.59 * * * \\
(0.20)\end{array}$ & $\begin{array}{c}0.59 * * * \\
(0.20)\end{array}$ & $\begin{array}{c}0.44 * * \\
(0.20)\end{array}$ & $\begin{array}{c}0.53 * * * \\
(0.20)\end{array}$ & $\begin{array}{l}0.35^{*} \\
(0.21)\end{array}$ & $\begin{array}{c}0.15 \\
(0.22)\end{array}$ & $\begin{array}{c}0.42 * * * \\
(0.15)\end{array}$ & $\begin{array}{c}0.35 * * \\
(0.15)\end{array}$ & $\begin{array}{c}0.41 * * * \\
(0.15)\end{array}$ & $\begin{array}{c}0.05 \\
(0.15)\end{array}$ \\
\hline PIL3 & & $\begin{array}{c}-2.05 * * * \\
(0.55)\end{array}$ & $\begin{array}{c}-2.08 * * * \\
(0.54)\end{array}$ & $\begin{array}{c}-1.85 * * * \\
(0.54)\end{array}$ & $\begin{array}{c}-1.85 * * * \\
(0.54)\end{array}$ & $\begin{array}{c}-2.04 * * * \\
(0.55)\end{array}$ & $\begin{array}{c}-2.07 * * * \\
(0.54)\end{array}$ & $\begin{array}{c}-1.46 * * * \\
(0.50)\end{array}$ & $\begin{array}{c}-1.51 * * * \\
(0.50)\end{array}$ & $\begin{array}{c}-0.77 * * \\
(0.38)\end{array}$ & $\begin{array}{c}-0.84 * * \\
(0.38)\end{array}$ & $\begin{array}{c}-0.78 * * \\
(0.38)\end{array}$ & $\begin{array}{c}-0.71 * * \\
(0.36)\end{array}$ \\
\hline SMC & & $\begin{array}{c}0.04 * * \\
(0.02)\end{array}$ & $\begin{array}{c}0.04 * * \\
(0.02)\end{array}$ & $\begin{array}{c}0.04 * * \\
(0.02)\end{array}$ & $\begin{array}{c}0.04 * * \\
(0.02)\end{array}$ & $\begin{array}{c}0.05 * * \\
(0.02)\end{array}$ & $\begin{array}{c}0.05 * * * \\
(0.02)\end{array}$ & $\begin{array}{c}0.00 \\
(0.02)\end{array}$ & $\begin{array}{c}0.01 \\
(0.02)\end{array}$ & $\begin{array}{l}0.02 * \\
(0.01)\end{array}$ & $\begin{array}{l}0.03 * * \\
(0.01)\end{array}$ & $\begin{array}{l}0.02^{*} \\
(0.01)\end{array}$ & $\begin{array}{c}0.04 * * * \\
(0.01)\end{array}$ \\
\hline ROA & & $\begin{array}{l}-0.03 \\
(0.06)\end{array}$ & $\begin{array}{l}-0.04 \\
(0.06)\end{array}$ & $\begin{array}{l}-0.01 \\
(0.06)\end{array}$ & $\begin{array}{l}-0.01 \\
(0.06)\end{array}$ & $\begin{array}{l}-0.03 \\
(0.06)\end{array}$ & $\begin{array}{l}-0.03 \\
(0.06)\end{array}$ & $\begin{array}{l}-0.04 \\
(0.21)\end{array}$ & $\begin{array}{l}-0.09 \\
(0.21)\end{array}$ & $\begin{array}{c}0.01 \\
(0.17)\end{array}$ & $\begin{array}{c}0.00 \\
(0.16)\end{array}$ & $\begin{array}{l}-0.00 \\
(0.17)\end{array}$ & $\begin{array}{l}-0.12 \\
(0.16)\end{array}$ \\
\hline LEV & & $\begin{array}{l}-0.00 \\
(0.01)\end{array}$ & $\begin{array}{l}-0.00 \\
(0.01)\end{array}$ & $\begin{array}{l}-0.00 \\
(0.01)\end{array}$ & $\begin{array}{l}-0.00 \\
(0.01)\end{array}$ & $\begin{array}{l}-0.00 \\
(0.01)\end{array}$ & $\begin{array}{l}-0.01 \\
(0.01)\end{array}$ & $\begin{array}{c}0.04 \\
(0.03)\end{array}$ & $\begin{array}{c}0.03 \\
(0.03)\end{array}$ & $\begin{array}{c}-0.01 \\
(0.02)\end{array}$ & $\begin{array}{l}-0.02 \\
(0.02)\end{array}$ & $\begin{array}{c}-0.01 \\
(0.02)\end{array}$ & $\begin{array}{l}-0.00 \\
(0.02)\end{array}$ \\
\hline GDP & & $\begin{array}{l}0.10 * * \\
(0.05)\end{array}$ & $\begin{array}{l}0.10^{* * *} \\
(0.04)\end{array}$ & $\begin{array}{l}0.10 * * \\
(0.05)\end{array}$ & $\begin{array}{l}0.10 * * \\
(0.05)\end{array}$ & $\begin{array}{l}0.10 * * \\
(0.05)\end{array}$ & $\begin{array}{l}0.10^{* * *} \\
(0.05)\end{array}$ & $\begin{array}{c}0.24 * * * \\
(0.07)\end{array}$ & $\begin{array}{c}0.20 * * * \\
(0.07)\end{array}$ & $\begin{array}{c}0.27 * * * \\
(0.06)\end{array}$ & $\begin{array}{c}0.26^{* * * *} \\
(0.06)\end{array}$ & $\begin{array}{c}0.27 * * * \\
(0.06)\end{array}$ & $\begin{array}{c}0.21 * * * \\
(0.05)\end{array}$ \\
\hline INFLT & & $\begin{array}{c}0.01 \\
(0.05)\end{array}$ & $\begin{array}{c}0.01 \\
(0.05)\end{array}$ & $\begin{array}{c}0.02 \\
(0.05)\end{array}$ & $\begin{array}{c}0.02 \\
(0.05)\end{array}$ & $\begin{array}{c}0.02 \\
(0.05)\end{array}$ & $\begin{array}{c}0.02 \\
(0.05)\end{array}$ & $\begin{array}{c}0.06 \\
(0.06)\end{array}$ & $\begin{array}{c}0.06 \\
(0.06)\end{array}$ & $\begin{array}{c}0.06 \\
(0.05)\end{array}$ & $\begin{array}{c}0.06 \\
(0.05)\end{array}$ & $\begin{array}{c}0.06 \\
(0.05)\end{array}$ & $\begin{array}{c}0.03 \\
(0.04)\end{array}$ \\
\hline Constant & & $\begin{array}{c}-4.58 * * * \\
(1.60)\end{array}$ & $\begin{array}{c}-5.25 * * * \\
(1.62)\end{array}$ & $\begin{array}{c}-5.56^{* * * *} \\
(1.62)\end{array}$ & $\begin{array}{c}-5.60 * * * \\
(1.64)\end{array}$ & $\begin{array}{c}-4.67 * * * \\
(1.56)\end{array}$ & $\begin{array}{c}-5.11 * * * * \\
(1.56)\end{array}$ & $\begin{array}{c}-4.14 * * * \\
(1.60)\end{array}$ & $\begin{array}{l}-2.47 \\
(1.73)\end{array}$ & $\begin{array}{c}-4.63 * * * \\
(1.20)\end{array}$ & $\begin{array}{c}-4.03 * * * \\
(1.26)\end{array}$ & $\begin{array}{c}-4.57 * * * \\
(1.22)\end{array}$ & $\begin{array}{l}-1.80 \\
(1.24)\end{array}$ \\
\hline Observations & & 325 & 325 & 324 & 324 & 324 & 324 & 287 & 287 & 287 & 287 & 287 & 287 \\
\hline Year dummy & & Yes & Yes & Yes & Yes & Yes & Yes & Yes & Yes & Yes & Yes & Yes & Yes \\
\hline Country dummy & & Yes & Yes & Yes & Yes & Yes & Yes & Yes & Yes & Yes & Yes & Yes & Yes \\
\hline $\mathrm{R}_{-}^{2} \mathrm{O}$ & & 0.656 & 0.639 & 0.639 & 0.637 & 0.679 & 0.683 & 0.636 & 0.647 & 0.782 & 0.784 & 0.782 & 0.810 \\
\hline Chi2 & & $235.2 * * *$ & $229.4 * * *$ & $193.6 * * *$ & $189.5 * * *$ & $281.5 * * *$ & $293.1 * * *$ & $317.4 * * *$ & $311.6 * * *$ & $963.2 * * *$ & $971.5 * * *$ & $960.3^{* * *}$ & $1131 * * *$ \\
\hline Breusch-Pagam & Chibar2 & 54.64 & 58.37 & 70.38 & 66.85 & 28.92 & 27.77 & 76.79 & 65.35 & 10.21 & 10.5 & 12.11 & 11.21 \\
\hline test & Pro $>$ Chibar2 & 0.000 & 0.000 & 0.000 & 0.000 & 0.000 & 0.000 & 0.000 & 0.000 & 0.056 & 0.058 & 0.062 & 0.062 \\
\hline
\end{tabular}


Standard errors in parentheses; $* * * \mathrm{p}<0.01, * * \mathrm{p}<0.05, * \mathrm{p}<0.1$. Table 2 shows the variables definitions.

Table 8: Robustness models- IFRS on value relevance of accounting numbers for banks (Eq5)

\begin{tabular}{|c|c|c|c|c|c|c|}
\hline & CBs IFRS & CBs No IFRS & IBs IFRS & IBs No IFRS & HBs IFRS & HBs No IFRS \\
\hline & (1) & (2) & (3) & (4) & (5) & (6) \\
\hline VARIABLES & PRICE* & PRICE* & PRICE* & PRICE* & PRICE* & PRICE* \\
\hline \multirow[t]{2}{*}{ EPS } & $7.64 * * *$ & $6.02 * * *$ & $13.80 * * *$ & 0.71 & 1.17 & 0.44 \\
\hline & $(1.73)$ & $(0.58)$ & (3.22) & $(0.88)$ & (1.93) & $(1.12)$ \\
\hline \multirow[t]{2}{*}{ BVPS } & $0.26^{*}$ & $0.31 * * *$ & 0.13 & 0.13 & $0.88^{* * *}$ & $0.77 * * *$ \\
\hline & $(0.15)$ & $(0.02)$ & $(0.52)$ & $(0.21)$ & $(0.10)$ & $(0.18)$ \\
\hline \multirow[t]{2}{*}{ SIZE } & $0.41 * * *$ & $0.12 * * *$ & $0.64 * * *$ & $0.47 * * *$ & 0.36 & $0.18 * *$ \\
\hline & $(0.12)$ & $(0.03)$ & $(0.21)$ & $(0.14)$ & $(0.29)$ & $(0.07)$ \\
\hline \multirow[t]{2}{*}{ PIL3 } & 0.70 & $0.81 * * *$ & $0.94 *$ & $1.16^{* * *}$ & -0.14 & $0.67 * * *$ \\
\hline & $(0.43)$ & $(0.15)$ & $(0.54)$ & $(0.30)$ & $(0.62)$ & $(0.18)$ \\
\hline \multirow[t]{2}{*}{ SMC } & $-0.03 * *$ & -0.00 & -0.03 & $-0.03 * *$ & 0.01 & $-0.02 * * *$ \\
\hline & $(0.01)$ & $(0.01)$ & $(0.02)$ & $(0.01)$ & $(0.02)$ & $(0.01)$ \\
\hline \multirow[t]{2}{*}{ ROA } & -0.12 & -0.06 & -0.01 & $-0.13^{* *}$ & -0.05 & $-0.20^{* *}$ \\
\hline & $(0.12)$ & $(0.05)$ & $(0.11)$ & $(0.06)$ & $(0.28)$ & $(0.09)$ \\
\hline \multirow[t]{2}{*}{ LEV } & 0.02 & $-0.05 * * *$ & -0.02 & $-0.03 * * *$ & $0.10^{* * *}$ & $-0.07 * * *$ \\
\hline & $(0.02)$ & $(0.01)$ & $(0.02)$ & $(0.01)$ & $(0.04)$ & $(0.01)$ \\
\hline \multirow[t]{2}{*}{ GDP } & $0.25^{* * *}$ & $0.13 * * *$ & $0.36^{* * *}$ & $0.14 * *$ & $0.34 * * *$ & $0.28 * * *$ \\
\hline & $(0.05)$ & $(0.03)$ & $(0.07)$ & $(0.06)$ & $(0.08)$ & $(0.04)$ \\
\hline \multirow[t]{2}{*}{ INFLT } & -0.10 & $0.03 * *$ & -0.13 & $0.05 * *$ & -0.02 & $0.04 * *$ \\
\hline & $(0.09)$ & $(0.01)$ & $(0.11)$ & $(0.02)$ & $(0.14)$ & $(0.02)$ \\
\hline \multirow[t]{2}{*}{ Constant } & $-4.72 * * *$ & $-2.29 * * *$ & $-6.41 * * *$ & $-3.91 * * *$ & $-7.28 * * *$ & $-3.23 * * *$ \\
\hline & $(0.83)$ & $(0.28)$ & (1.40) & $(0.77)$ & $(2.20)$ & $(0.46)$ \\
\hline Observations & 324 & 411 & 233 & 92 & 168 & 119 \\
\hline Adjusted $\mathrm{R}^{2}$ & 0.411 & 0.643 & 0.427 & 0.264 & 0.701 & 0.645 \\
\hline $\mathrm{F}$ & $25.99 * * *$ & $83.09 * * *$ & $20.19 * * *$ & $4.628 * * *$ & $44.41 * * *$ & $24.78 * * *$ \\
\hline
\end{tabular}

Standard errors in parentheses; $* * * \mathrm{p}<0.01, * * \mathrm{p}<0.05,{ }^{*} \mathrm{p}<0.1$. Table 2 shows the variables definitions. 


\begin{tabular}{|c|c|c|c|c|c|c|}
\hline & \multicolumn{2}{|c|}{ CBs } & \multicolumn{2}{|c|}{ IBs } & \multicolumn{2}{|c|}{ HBs } \\
\hline & Good News & Bad News & Good News & Bad News & Good News & Bad News \\
\hline & (1) & (2) & (3) & (4) & (5) & (6) \\
\hline VARIABLES & $(\mathrm{EPS} / \mathrm{PRICE})^{*}$ & (EPS/ PRICE)* & (EPS/ PRICE)* & (EPS/ PRICE)* & (EPS/ PRICE)* & (EPS/ PRICE)* \\
\hline \multirow[t]{2}{*}{ RETURN } & $0.25 * * *$ & $0.04 * * *$ & -0.02 & $0.06^{*}$ & 0.03 & 0.01 \\
\hline & $(0.02)$ & $(0.01)$ & $(0.02)$ & $(0.03)$ & $(0.02)$ & $(0.02)$ \\
\hline \multirow[t]{2}{*}{ SIZE } & $0.04 * * *$ & 0.00 & -0.00 & -0.01 & -0.01 & 0.00 \\
\hline & $(0.01)$ & $(0.01)$ & $(0.01)$ & $(0.01)$ & $(0.02)$ & $(0.01)$ \\
\hline \multirow[t]{2}{*}{ PIL3 } & -0.03 & -0.05 & 0.02 & -0.03 & -0.00 & $-0.02 *$ \\
\hline & $(0.05)$ & $(0.04)$ & $(0.02)$ & $(0.02)$ & $(0.03)$ & $(0.01)$ \\
\hline \multirow[t]{2}{*}{ SMC } & -0.00 & 0.00 & -0.00 & 0.00 & 0.00 & 0.00 \\
\hline & $(0.00)$ & $(0.00)$ & $(0.00)$ & $(0.00)$ & $(0.00)$ & $(0.00)$ \\
\hline \multirow[t]{2}{*}{ ROA } & $0.05 * * *$ & -0.01 & 0.01 & 0.00 & $-0.05 * * *$ & $0.01 * *$ \\
\hline & $(0.02)$ & $(0.01)$ & $(0.01)$ & $(0.00)$ & $(0.01)$ & $(0.01)$ \\
\hline \multirow[t]{2}{*}{ LEV } & $-0.00 * *$ & 0.00 & -0.00 & 0.00 & $-0.00^{*}$ & 0.00 \\
\hline & $(0.00)$ & $(0.00)$ & $(0.00)$ & $(0.00)$ & $(0.00)$ & $(0.00)$ \\
\hline \multirow[t]{2}{*}{ GDP } & $-0.02 * * *$ & 0.00 & -0.00 & -0.01 & -0.00 & -0.00 \\
\hline & $(0.01)$ & $(0.01)$ & $(0.00)$ & $(0.00)$ & $(0.00)$ & $(0.00)$ \\
\hline \multirow[t]{2}{*}{ INFLT } & 0.01 & 0.00 & $0.01 * * *$ & -0.00 & $-0.01 * *$ & -0.00 \\
\hline & $(0.00)$ & $(0.01)$ & $(0.00)$ & $(0.00)$ & $(0.00)$ & $(0.00)$ \\
\hline \multirow[t]{2}{*}{ Constant } & $-0.38 * * *$ & -0.07 & -0.01 & 0.10 & $0.26^{* *}$ & -0.04 \\
\hline & $(0.11)$ & $(0.11)$ & $(0.06)$ & $(0.07)$ & $(0.12)$ & $(0.04)$ \\
\hline Observations & 319 & 219 & 154 & 91 & 93 & 103 \\
\hline R-squared & 0.40 & 0.04 & 0.11 & 0.12 & 0.23 & 0.25 \\
\hline $\mathrm{F}$ & $25.83 * * *$ & $1.071 * * *$ & $2.325 * * *$ & $1.386 * * *$ & $3.216 * * *$ & $3.945 * * *$ \\
\hline
\end{tabular}

